\title{
Optimal Compensation Contract When Managers Can Hedge
}

\author{
Huasheng Gao* \\ Sauder School of Business \\ University of British Columbia \\ 2053 Main Mall, Vancouver, BC V6T $1 Z 2$ \\ 604.657.4458 \\ huasheng.gao@sauder.ubc.ca
}

December, 2008

\begin{abstract}
:
This paper examines optimal compensation contracts when executives can hedge their personal portfolios. In a simple principal-agent framework, I predict that the CEO's pay-performance sensitivity decreases with the executive hedging cost. Empirically, I find evidence supporting the model's prediction. Providing further support for the theory, I show that shareholders also impose high sensitivity of CEO wealth to stock volatility via compensation contracts when managers can hedge. In addition to providing higher-power contracts, shareholders increase financial leverage to resolve the executive-hedging problem. Moreover, executives with lower hedging costs hold more exercisable in-the-money options, have weaker incentives to cut dividends, and pursue fewer corporate diversification initiatives. Overall, the ability to hedge firm risk undermines executive incentive and enables managers to bear more risk, thus affecting governance mechanisms and managerial actions.
\end{abstract}

JEL Classification: G32; J33; J41

Keywords: Executive compensation; Hedging; Equity incentives;

\footnotetext{
* I thank Kai Li, Hernan Ortiz-Molina, Alan Kraus and Ralph Winter for their supervision and insightful discussions. I also thank Murray Carlson, Robert Heinkel, Sung Bae, Florian Peters, Jeff Coles, Chao Chen, Kose John, and seminar participants at University of British Columbia, California State University Fullerton, University of Hong Kong, City University of Hong Kong, the Second Conference on Asia-Pacific Financial Markets, 2008 Midwest Finance Association Meeting, 2008 Western Finance Association Conference, 2008 China International Finance Conference, and 2008 FMA Doctoral Student Consortium for helpful comments. All errors are mine.
} 
An executive who hedges is a little bit like the captain of a ship who sees an iceberg up ahead and heads for his lifeboat without waking the sleeping passengers.

Louis Lavelle, Business Week, 2001, Issue 15

\section{Introduction}

Equity-based compensation is widely regarded as an effective way to align managers' interests with those of their shareholders. Most of the literature on executive compensation is built on an essential assumption that managers cannot hedge their incentive portfolios. However, executives can certainly employ a number of financial instruments to hedge the risk in their compensation packages. As reported by Lavelle (2001), the disclosed executive hedging transactions have doubled from 1996 to 2001. Ip (1997) further points out that the disclosed hedging activities are far below the actual level. As shown by Bettis et al. (2001), there has been a huge increase in the development and use of financial derivatives that enable corporate insiders to hedge their stock ownership in their firms. Moreover, Stulz (1984 p.139) explicitly states: "It would be interesting to show how the choice of the management compensation schemes depends on the opportunities managers have to hedge.”

This paper analyzes the impact of managerial hedging on executive compensation, from both a theoretical and empirical perspective. I first extend Holmstrom and Milgrom (1987)'s principal-agent model by allowing a manager to costly hedge her incentive portfolio. The access to the hedging market increases the manager's ability to bear risk, and it also decreases her incentive to exert effort. In equilibrium, shareholders should provide a higher-power contract so that the manager's after-hedging incentive is closer to the optimal level. The central empirical prediction of the model is that the pay-performance sensitivity 
in compensation contracts decreases alongside the manager's hedging cost.

In the empirical tests, I use two variables to measure the executive hedging cost. The first one is a dummy variable indicating whether or not the firm has listed options on the option exchanges. The idea behind this variable is straightforward. When the firm has publicly tradable options, it will be easier and less costly for managers to unwind their incentive pay through derivative markets (e.g., buying put options, or short selling call options). As to my second proxy, for firms with traded options I measure the hedging cost using the average daily trading volume of the firms' options. Clearly, a high volume indicates high liquidity and active trading of the firm's derivatives, which lowers the cost of making derivative transactions. Consistent with the paper's focus, these two proxies capture the opportunity that managers have to hedge. Based on a large set of compensation data, I then provide empirical evidence supporting my model’s prediction.

To further my understanding of how managerial hedging influences compensation contracts, I then examine the sensitivity of CEO wealth to stock return volatility which captures the convexity of the relation between CEO wealth and stock price. As suggested by prior literature, the optimal convexity in CEO pay is determined by the benefit of inducing the CEO to take risky value-increasing projects and the cost of compensating the risk-averse executive to bear risk. When managers have better opportunities to hedge, the disutility imposed by the risk in their incentive pay will become smaller, and thus the optimal convexity should be higher. Consistent with this view, I find that a CEO with lower hedging cost receives an incentive pay of greater sensitivity to stock volatility.

Moreover, stock-based pay is one of a few mechanisms that shareholders can use to 
discipline managers. Another related question is whether or not shareholders use other governance policies to resolve shareholder-manager agency problem in response to executive hedging. Specifically, I deal with this question by investigating corporate capital structure. As a substitute for incentive contracts, existing studies suggest that debt is used as a powerful tool to induce managers to increase firm value. Shareholders are supposed to use more debt when it is easier for their managers to unwind incentive pay, because the incentive contract is less effective in this situation. Consistent with this view, I find that firms have higher debt levels when their managers have better opportunities to hedge. This evidence also supports the implication that shareholders do use other mechanisms (besides offering more higher-power contracts), like alterations to the capital structure, to overcome the executive-hedging problem.

Whether or not a manager can hedge will clearly influence the way she deals with her personal portfolio. To understand this issue, I examine how executives rebalance their personal portfolios when hedging transactions are possible. Given the fact that a big portion of managers' wealth is tied to their own firms, these under-diversified risk-averse managers tend to have strong incentives to diversify their portfolios by unwinding their equity holdings. Therefore, they should be eager to exercise their stock options when those options become exercisable and in the money. However, when managers can hedge their compensation portfolios to some extent, they will suffer less disutility from bearing risk, and will be less eager to exercise their vested options. In other words, managers are supposed to hold more exercisable in-the-money options when they have a low hedging cost. My empirical analysis supports this view, based on varying measures of option holding. 
A natural extension of my study is to examine how executive hedging influences managers' decisions on corporate policies. The basic idea is quite intuitive: managers who can hedge are less influenced by their incentive pay. In particular, I examine the corporate dividend payout in the presence of managerial hedging. Executive stock options induce managers to reduce corporate dividends, because the payment of dividends, ceteris paribus, reduces the value of call option. However, if managers have hedged their incentive portfolios, they will not have that strong motivation to cut dividends, simply because paying dividends will have less of a negative effect on their personal wealth. Empirically, I provide evidence that executive hedging weakens the negative relation between stock option compensation and dividend payout. This result also supports a broader view that managerial hedging undermines the influence of incentive pay on management decision making.

Finally, this paper examines the impacts of executive hedging on corporate diversification. To the extent that firm diversification is another way for managers to reduce risk, I argue that hedging a personal portfolio and making corporate diversification are substitutes for executives to decrease the idiosyncratic firm risk they face. Consistent with this argument, I find that managers diversify their companies less when it is less costly to hedge their incentive pay.

This paper makes several contributions to the literature. First, it identifies executive hedging cost as an important determinant to executive compensation structure. To my best knowledge, this is the first paper that empirically examines how management compensation schemes depend on managers' opportunities to hedge. In addition, my research also furthers our understanding of capital structure as a substitute mechanism for compensation contracts 
in resolving managerial agency problems.

Second, this article provides insight into managers’ personal financial decision-making. The exercise behavior of executive stock options is quite an important topic for compensation research, because it is crucial to the valuation of employee stock options (Huddart and Lang (1996)). My paper contributes to this literature by documenting the important impact of managerial hedging on the managers' option-exercising decisions.

Third, beyond the implications for CEO pay, this study also improves our understanding of managerial incentive in making corporate policies. Stock-based compensation is an often-cited factor that influences corporate decisions. This influence clearly depends on whether or not managers can hedge. Therefore, this research sheds more light on dividend policy and corporate diversification through the lens of executive hedging.

Lastly, this paper documents indirect evidence that executives tend to use public derivative markets to unwind their incentive portfolios and that shareholders take those publicly-tradable derivatives into consideration when designing compensation contracts.

The article proceeds as follows. Section 2 introduces some background and related literature. Section 3 presents the model and provides the empirical prediction. In Section 4, I describe the data source and sample construction. Section 5 reports the empirical results. Finally, Section 6 concludes.

\section{Background on Executive Hedging}

Current legal system and managerial contracts play a very limited role in governing executive hedging transactions. It is legal for the managers to trade derivatives on stocks of their own firms, since Section 16 (c) of the Securities and Exchange Act of 1934 and Rule 
16c-4 only forbid managers from selling their firms’ stock short. As summarized by Schizer (2000), although existing executive contracts and security law have put some barriers to managerial hedging, their gaps are still significant. Bebchuk et al. (2002) suggest that executives have lots of freedom to access the financial market to hedge. As it is pointed out by Garvey (1997), the direct bans on management hedging are costly to enforce because the securities market is sufficiently rich and liquid that the manager's participation in hedging cannot be perfectly controlled.

Business practice has long witnessed the prevalence of executive hedging activities. Puri (1997) reports that a growing number of banks are marketing derivatives to help executives hedge. In the Wall Street Journal, Simon (2000) states "it is impossible to precisely gauge the popularity of these hedges, but derivatives specialists suggest that hundreds, perhaps even a couple of thousand, are executed each year.” Schizer (2000) points out that the growing importance of equity-based compensation is accompanied by the simultaneous increase in the derivative instruments by which managers can use to hedge.

Both the academic and the practitioner have expressed great concern over the managerial hedging issue. The Economist (1999) states "Such hedging is wholly against the spirit of the massive awards of shares and share options.” Ofek and Yermack (2000) and Antle and Smith (1986) argue that the optimal contracting model should take into account the managers' freedom to hedge away the risk in their compensation.

Despite the significant literature on executive compensation, the understanding of managerial hedging is quite limited. Jin (2002) and Garvey and Milbourn (2003) study the case in which executives can trade market indices. Jin (2002) mainly addresses the effects of 
firm idiosyncratic risk and systematic risk on compensation contracts; the latter one focuses on justifying the rare use of relative performance evaluation. My paper complements their research by examining the case when managers can diversify their firm-specific risk exposure. More importantly, this article provides an extensive empirical analysis on the influence of managerial hedging on compensation contracts and corporate policies. ${ }^{1}$

\section{The Model}

This section presents a standard principal-agent model in which the manager can hedge her equity holdings at a certain hedging cost. The structure of the model follows Holmstrom and Milgrom (1987).

One risk-averse manager works in a firm owned by risk-neutral investors. The manager's utility function is given by:

$$
U(w, a)=-\exp \left[-\eta\left(w-\frac{c}{2} a^{2}\right)\right]
$$

where $w$ is the manager's total wage, $a$ is her effort level, $\eta$ is the coefficient of risk aversion, and $c>0$ is a constant reflecting the manager's aversion to effort. The firm's cash flow, $p$, equals to the manager's effort plus noise:

$$
p=a+\varepsilon
$$

where $\varepsilon$ is normally distributed with zero mean and variance $\sigma^{2}$. The manager gets a compensation package in the form:

$$
t+s p
$$

where $t$ is the fixed pay level and $s$ is the performance-based component of her compensation. Equivalently, $t$ is the manager's fixed salary and $s$ is her share of the firm.

\footnotetext{
${ }^{1}$ Other related theoretical work includes Bisin et al. (2006), Ozerturk (2006), and Acharya and Bisin (2005).
} 
Like prior literature, I restrict my attention to a linear contract for algebra simplification.

The manager has the access to the hedging market, and can trade her shares at the hedging cost of $\frac{\phi}{2} x^{2}$, where $x$ stands for the number of shares traded and $\phi>0$ is a constant capturing her cost of hedging. This model allows a very general form of hedging without being limited to one particular hedging instrument. Like Garvey and Milbourn (2003), I am assuming a strict convex function for the hedging cost, reflecting the reasonable assumption that it is costly for managers to take additional steps to either augment or offset their exposure to their own firms’ equity. If one interprets the hedging cost as the transaction expense during the asset trading, this convexity is also consistent with the evidence that transaction cost in financial markets is a convex function of trading size (See e.g. Korajczyk and Sadka (2004), and Breen et al. (2002)). Another interpretation on this hedging cost can be the probability for the manager to be caught in the hedging transactions. As the manager hedges more, it will be more likely for her to be detected by shareholders and suffer some corresponding penalty.

The sequence of the game is described as follows:

Stage 1 . The shareholders optimally set the compensation rule $(t, s)$ to maximize net-of-wage firm value, taking into account the subsequent hedging behavior and the effort of the manager.

Stage 2. The manager trades her shares in the hedging market, where the share price reflects the rational expectation about her subsequent effort level.

Stage 3. The manager chooses her effort. Both the hedging transaction and effort level are chosen to maximize the manager's own utility. 
Stage 4. The firm's cash flow is realized and the manager consumes her wealth.

The manager's wealth after hedging is:

$$
w=t+(s+x) p-x E\left[p^{0}\right]-\frac{\phi}{2} x^{2}
$$

where $E\left[p^{0}\right]$ is the expected firm value at the hedging market. Since the hedging occurs before the effort is made, $E\left[p^{0}\right]$ reflects the expected managerial effort level $a^{0}(x)$, and in particular $E\left[p^{0}\right]=a^{0}(x)$. The notation $a^{0}(x)$ indicates that the hedging market rationally infers the manager's subsequent effort based on the number of shares hedged. Rewriting the manager's objective in terms of her certainty-equivalent wealth and we thus arrive at the following reformulation:

$$
\operatorname{Max}_{a, x} t+(s+x) a-\frac{c}{2} a^{2}-\frac{\eta}{2}(s+x)^{2} \sigma^{2}-\frac{\phi}{2} x^{2}-x a^{0}(x)
$$

First-order conditions with respect to $a$ and $x$, respectively, lead to:

$$
\begin{aligned}
& c a^{*}=s+x^{*} \\
& a^{*}-\eta\left(s+x^{*}\right) \sigma^{2}-\phi x^{*}-a^{0}(x)-x \frac{d a^{0}(x)}{d x}=0
\end{aligned}
$$

The rational expectation condition implies:

$$
a^{0}(x)=a^{*}=\frac{s+x^{*}}{c}
$$

Equations (6)-(8) result in the following solution to the manager's optimization problem:

$$
\begin{aligned}
& a^{*}=\frac{\phi+1 / c}{c\left(\phi+\eta \sigma^{2}+1 / c\right)} s \\
& x^{*}=\frac{-\eta \sigma^{2}}{\phi+\eta \sigma^{2}+1 / c} s
\end{aligned}
$$

As implied from Equation (9), the effort-compensation sensitivity, $\frac{d a^{*}}{d s}=\frac{\phi+1 / c}{c\left(\phi+\eta \sigma^{2}+1 / c\right)}$, is increasing in $\phi$. This result suggests that managerial effort will be more sensitive to her 
stock-based pay when the hedging is costly to implement. Equation (10) shows the intuitive result that the manager hedges more when the hedging cost $\phi$ is smaller, for a given level of $s$. When $\phi=0$, I obtain $x^{*}=-\frac{\eta \sigma^{2}}{\eta \sigma^{2}+1 / c} s$. This result means that, even in the case of zero hedging cost, the manager will not hedge all her exposure to the firm-specific risk. Instead, she will still hold a certain number of shares which are proportional to the initial equity given by the shareholders, because the manager can exert effort to increase her payoff. This result also implies that stock-based compensation can still provide managers some incentive even when managers can freely hedge. When $\phi \rightarrow+\infty$, I obtain $x^{*}=0$, suggesting that the manager will not hedge when hedging is too costly.

The shareholders maximize the net-of-wage firm value, which is:

$$
\begin{aligned}
& \operatorname{Max}_{a, t, s, x} E[p-t-s p] \\
& \text { subject to } \\
& a, x \in \arg \max _{a, x} E\left\{-\exp \left[-\eta\left(w-\frac{c}{2} a^{2}\right)\right]\right\} \\
& E\left\{-\exp \left[-\eta\left(w-\frac{c}{2} a^{2}\right)\right]\right\} \geq-\exp (-\eta \bar{w})
\end{aligned}
$$

where $\bar{w}$ denotes the manager's reservation wage.

Based on Equations (9) and (10), the principal' problem can be rewritten as $\operatorname{Max}_{a, x, t, s}(1-s) a-t$ subject to

$$
\begin{aligned}
& a=\frac{\phi+1 / c}{c\left(\phi+\eta \sigma^{2}+1 / c\right)} s \quad x=\frac{-\eta \sigma^{2}}{\phi+\eta \sigma^{2}+1 / c} s \\
& t+(s+x) a-\frac{c}{2} a^{2}-\frac{\eta}{2}(s+x)^{2} \sigma^{2}-\frac{\phi}{2} x^{2}-x a^{0}(x)=\bar{w} \\
& a^{0}(x)=\frac{x+s}{c}
\end{aligned}
$$

Substituting for the value of $t$ in the individual-rationality constraint and maximizing with respect to $s$ and $t$, I obtain the following solution for managerial effort, the manager's 
after-hedging equity holding, and optimal compensation policy:

$$
\begin{aligned}
& a^{*}=\frac{1}{c} \frac{\phi+1 / c}{\left(1+c \eta \sigma^{2}\right)(\phi+1 / c)+c \eta^{2} \sigma^{4}} \\
& s^{*}+x^{*}=\frac{\phi+1 / c}{\left(1+c \eta \sigma^{2}\right)(\phi+1 / c)+c \eta^{2} \sigma^{4}} \\
& s^{*}=\frac{\phi+\eta \sigma^{2}+1 / c}{\left(1+c \eta \sigma^{2}\right)(\phi+1 / c)+c \eta^{2} \sigma^{4}}
\end{aligned}
$$

Notably, when $\phi \rightarrow+\infty, \quad s^{*}=\frac{1}{1+c \eta \sigma^{2}}$ which is exactly Holmstrom and Milgrom (1987)'s solution with no executive hedging. The analysis above yields the following result: Proposition: The optimal pay-performance sensitivity, $s^{*}$, is decreasing in the managerial hedging cost.

The derivation of this proposition is straightforward. It is easy to show, from Equation (14), that $\frac{d s^{*}}{d \phi}=-\frac{\eta \sigma^{2}}{\left[\left(1+c \eta \sigma^{2}\right)(\phi+1 / c)+c \eta^{2} \sigma^{4}\right]^{2}}<0$. The economic intuition is as follows. A decrease in the hedging cost reduces the manager's disutility of bearing risk since the manager is able to hold less after-hedging stock shares (Equation (13)). In other words, managerial hedging enhances the manager's ability to bear risk. Given the fact that an optimal contract is always about the trade-off between incentive and risk, managers with high risk-bearing ability should be given a high-power contract. Another simple interpretation is as below. If managers can costly undo the incentive of a compensation contract, the contract will be made to provide more incentive to start with so that the contract is closer to what is optimal once managers undo part of the incentive.

As we see, hedging transactions that occur before managerial effort undermine the effectiveness of incentive contracting. This problem is therefore interesting only if direct 
bans on management hedging are difficult to enforce. The model effectively assumes that managers' participation in the hedging market cannot be perfectly controlled by firm shareholders. The assumption is valid because managers' trades in their own firms' securities are verifiable only by testimony from parties who know the managers personally (Muelbroek (1992)). In practice, the manager's personal portfolio is not publicly disclosed; it is difficult and costly for shareholders to monitor. Current literature, like Garvey (1997) and Ofek and Yermack (2000), also provides evidence in favor of this assumption.

\section{Data Construction and Sample Selection}

\subsection{Measures of CEO Incentive}

I use two complementary variables to measure the CEO's incentive pay.

Jensen and Murphy (1990)'s Pay-Performance Sensitivity (PPS). Following Jensen and Murphy (1990), PPS is the dollar value of a CEO’s wealth change relative to 1,000 dollar change of shareholders' value. Although managers can receive pay-performance incentives from a variety of sources, the vast majority of these incentives are due to ownership of stock and stock options. Similar to Aggarwal and Samwick (2003) and Core and Guay (1999), I compute this sensitivity as the dollar value change of stock and options held by a CEO relative to a $\$ 1,000$ shareholder return.

For stock, the PPS is simply the fraction of the firm that the executive owns. The PPS for options is the fraction of the firm's stock on which the options are written multiplied by the options’ delta. I use the method developed by Core and Guay (2002) to estimate option deltas, which uses the Black-Scholes (1973) option valuation model as modified by Merton (1973) to adjust dividend payouts. Their method can avoid the cost and difficulty of 
collecting option data from various proxy statements, since it requires information from only the most recent proxy statements. More important, they show that their estimates are effectively unbiased and 99\% correlated with the measures that would be obtained if the parameters of a CEO’s option portfolio were completely known.

Core and Guay (1999)'s Portfolio Equity Incentive (PEI). Following Core and Guay (1999), PEI is defined as the change in the dollar value of the CEO's stock and option holding for $1 \%$ change in the stock price. As pointed by them, $P E I$ is actually equal to $P P S$ multiplied by the firm’s market value of equity, and divided by $\$ 100,000$.

Although both the two variables measure how close the CEO's pay is related to shareholder wealth, they differ in the underlying assumptions about what drives managerial incentives. PPS measures the CEO's wealth change relative to dollar value change of shareholder wealth, under the assumption that incentives increase with a manager's fractional ownership of the firm. PEI captures the CEO's wealth change compared to the percentage change of shareholder wealth, by assuming that incentives increase with a manager’s dollar ownership of the firm (Core and Guay (1999)).

As argued by Baker and Hall (1998), which measure is more appropriate depends on how CEO actions are assumed to influence shareholder value. When CEO actions primarily affect firm dollar return (like purchasing a corporate jet), the appropriate incentive measure is $P P S$. In contrast, when CEO actions primarily affect firm percentage returns (such as corporate reorganization and strategic redirection), $P E I$ is the appropriate measure for executive incentive. This paper is not intended to contribute to the debate about measuring executive incentives; for the robustness purpose, I use both measures. 


\subsection{Measures of Executive Hedging Cost}

The key explanatory variable is the cost of managerial hedging, which can be equivalently interpreted as the hedging opportunities that managers have. I propose two proxies to measure these opportunities. The first is an Option dummy, which equals one if the firm's option is traded in at least one of the six U.S. option exchanges, and zero otherwise. ${ }^{2}$ The economic intuition behind this variable is quite straightforward. When the firm's option is publicly tradable, managers will have better opportunities to undo their equity holding in the derivatives market, which decreases managerial hedging cost. In other words, managerial hedging cost will be high when Option=0, and relatively low otherwise. Moreover, this Option dummy can be largely regarded as an exogenous variable to the company itself, to the extent that the decision to list a firm's option is made by the option exchanges not by the firm (Mayhew and Mihov (2004)). ${ }^{3}$

The second proxy is the firm's option trading volume, which reflects the liquidity, activeness, and development of the firm's option in the derivative market. Intuitively, a high volume indicates that it is relatively easy and convenient to trade the firm's options.

\subsection{Control Variables}

Besides the hedging cost, I also include in my empirical study a set of control variables that influence compensation policies as suggested by existing literature. These control variables are listed as follows.

CEO Age. Career concern is another factor influencing managerial behavior and firms’

\footnotetext{
2 The six exchanges include American Stock Exchange, Boston Options Exchange, Chicago Board Options Exchange, International Securities Exchange, Pacific Exchange, and Philadelphia Stock Exchange.

${ }^{3}$ Unlike the stock market, where firms apply to be listed, decisions to list options are made within the exchanges. Generally, stocks are selected for option listing by committees composed of members of the exchange, after soliciting feedback from the general membership.
} 
compensation policies. Gibbons and Murphy (1992) provide theory and evidence showing that firms will use more equity-based compensation for older CEOs. Like them, I control for the CEO age to take account of the manager's horizon problem. Moreover, a CEO’s age may also be associated with her reputation, personal wealth, and risk aversion.

Firm Risk. Optimal contracting involves the trade-off between providing incentives and risk sharing between managers and shareholders, such that incentive level should decrease with firm risk. As a common approach, I measure the firm’s risk by using the stock return variance based on the firm's monthly returns of past five years.

Firm Size. Existing literature shows that the cross-sectional level of a CEO's incentive compensation changes predictably with firm size (Jin (2002) and Baker and Hall (1998)). To control for this size effect, I compute firm size as the natural logarithm of firm’s market value of equity.

Leverage Ratio. If managers have strong incentives to maximize shareholders' value, debtholders will demand higher risk premium for providing capital considering that managers will transfer wealth from debtholders to equityholders by pursuing risky investment projects. Based on this intuition, John and John (1993)'s model predicts a negative relation between leverage and pay-performance sensitivity. Therefore, I include in my empirical study the book-value ratio of firm’s long-term debt over total assets.

Market-to-Book Ratio(M/B). As suggested by numerous studies (e.g., Yermack (1995)), when companies have large growth opportunities, shareholders have greater difficulty evaluating managers' decisions, and thus should provide managers with more stock-based compensation. I use $M / B$ to control for the firm's growth opportunity. 
Cash. In addition to offering incentives, equity-based pay also provides companies an opportunity to save cash. Hall and Liebman (1998) suggest that scarcity of cash may lead firms to substitute cash payment with equity compensation. Therefore, availability of cash holding may be important determinant in setting executive compensation. I measure Cash as the ratio of cash and short-term investment over the firm's total assets.

Moreover, existing literature also shows that companies use more equity-based compensation when firm performance is high (e.g., Core and Guay (1999)). To account for firm performance, I also include return on equity $(R O E)$ and the firm's annual stock return as additional controls.

\subsection{Data Source}

My data come from four primary sources. Firm stock returns are obtained from CRSP, the compensation data come from Standard and Poor's ExecuComp, firm accounting information is from Compustat, and option trading data come from OptionMetrics. OptionMetrics is a comprehensive source of historical price and implied volatility data for all U.S. exchange-listed equity options, starting from January 1996. All of the monetary variables are measured in 2000-constant dollars. To ensure some outliers in the data are not driving my results, I winsorize all the continuous variables at the $1^{\text {st }}$ and $99^{\text {th }}$ percentiles.

My final sample consists of 13,314 CEO-year observations from 1996 to 2005, 74\% of which have options traded on the U.S. option exchanges (9,837 CEO-year observations). This big proportional number is not surprising since the companies in ExecuComp are usually the 1,500 biggest U.S. public firms. 


\section{Empirical Results}

My model predicts a negative relation between pay-performance sensitivity and executive hedging cost. The empirical test consists of regressions of pay-performance sensitivity on the hedging cost. This setting follows naturally from the model: shareholders set the executive pay as taking account of managers' hedging behavior and other factors.

\subsection{Summary Statistic}

\section{[Insert Table 1 Here]}

Panel A of Table 1 reports the firm's characteristics. The median firm is quite large; its market capitalization of equity is $\$ 1,339$ million. The sample firms are performing well with median market-to-book ratio $(M / B)$ of $2.14, R O E$ of $12 \%$, and annual stock return of 10.5\%. Moreover, those firms are moderately levered with the median leverage ratio of $17 \%$, and have sizeable cash holding with a median Cash ratio of 5\%. For the firms with publicly tradable options, the mean and median daily option trading volume is 990 and 139 contracts, respectively, indicating that this variable is highly skewed. The median CEO is 56 years old.

The variable, $P P S$, has a mean of $\$ 26$ per $\$ 1,000$ shareholder return and a median of $\$ 7$; this number is quite similar to that reported by Hall and Liebman (1998). ${ }^{4}$ The median PEI is $\$ 112,000$ change in CEO wealth for a $1 \%$ change in stock price, and this variable is substantially skewed with an average value of $\$ 389,000$. The $P E I$ value in my sample is a little smaller than that in Core and Guay (1999). The difference is consistent with the decreasing role of options in compensation after the downturn of the stock market in the early 2000s. ${ }^{5}$ As complementing measures for managerial incentives, PPS and PEI are

\footnotetext{
4 The pay-performance sensitivity reported in Hall and Liebman (1998) is \$25 at the mean and \$5.29 at the median.

${ }^{5}$ Core and Guay (1999)'s sample is from 1992 to 1996.
} 
positively correlated; their correlation coefficient is 0.46 .

I report the correlations between the explanatory variables in Panel $\mathrm{B}$. With the exception of the large positive correlations among Ln(Volume), Firmsize, and Firmsize ${ }^{2}$, all of the correlations are below 0.4 in magnitude. Both Option and $L n$ (Volume) are positively correlated with firm size, which is consistent with the finding that large firms are more likely to have listed options and large option trading volume (Mayhew and Mihov (2004)). This fact also suggests that it is important to control for the size effect in the regressions.

\subsection{Managerial Hedging Cost and Incentive Pay}

Existing literature on CEO compensation proposes the use of ordinary least squares (OLS), median and fixed effect regressions. I perform all of the three types and find qualitatively similar results. In particular, my tests on the relation between the hedging cost and incentive pay are based on the following equation:

$$
\begin{aligned}
& \text { Incentive }_{i t}=a_{0}+a_{1} \text { Option }_{i t}+a_{2} \text { Ln }\left(\text { Volume }_{i t}+a_{3} \text { FirmSize }_{i t-1}+a_{4} \text { FirmSize }_{i t-1}^{2}\right. \\
& +a_{5} C D F(\text { Variance })_{i t-1}+a_{6} M / B_{i t-1}+a_{7} R O E_{i t-1}+a_{8} \text { Leverage }_{i t-1}+a_{9} \text { Age }_{i t}+a_{10} \text { Cash }_{i t-1} \\
& +a_{11} \text { Stockreturn }_{i t-1}+\text { IndustryDummy / Firm Fixed Effects }+ \text { YearDummy }+\varepsilon_{i t}
\end{aligned}
$$

where $i$ indexes firms and $t$ indexes year. The dependent variable is the pay-performance sensitivity in a CEO’s compensation package, measured by PPS and PEI. I include the Fama and French (1997)'s 48 industry dummies and year dummies to control for industry and time variation in executive pay schemes. Throughout the entire empirical test, p-values for the OLS regressions are computed based on robust standard errors clustered on the firm level. Estimating positive coefficients for both $a_{1}$ and $a_{2}$ would be consistent with the prediction that the managerial hedging cost is negatively associated with incentive pay.

\section{[Insert Table 2 Here]}


Table 2 reports the regression results, using the Option dummy as the proxy for the hedging cost. The coefficient on Option is both economically and statistically significant in all six regressions. In Regression (1), the dependent variable in this OLS model is PPS. The coefficient of Option is about 3.2 and is significant at the $1 \%$ level. This result indicates that a change of Option from zero to one is associated with an increase in PPS by $\$ 3.2$ per $\$ 1,000$ shareholder wealth change, comparing to the median PPS of $\$ 7$. The coefficients of other control variables are generally consistent with existing empirical studies. In particular, I find that PPS tends to be higher for firms of smaller size, higher growth potential, better accounting performance, lower leverage ratio, older CEOs, and less liquidity constraints.

Table 1 shows clearly the right skewness of the compensation data. For this reason, the median as a measure of the center of a distribution is more robust than mean. Following Aggarwal and Samwick (1999) and Jin (2002), I therefore use median regression to estimate PPS in Column (2). Median regression minimizes the sum of absolute deviations rather than the sum of squared deviations and can thus increase the precision of estimating executive incentives (Aggarwal and Samwick (1999)). The corresponding p-values are computed according to bootstrapped standard errors based on 20 replications.

In Model (2), all the independent variables have qualitatively similar coefficients to those in Column (1). The variable Option has a coefficient of 0.76 and it is significant at the $1 \%$ level. Not surprisingly, all the median regression estimates are well below the magnitude of my OLS estimates of PPS, because of the right skewness of the compensation data. ${ }^{6}$

\footnotetext{
6 Aggarwal and Samwick (1999) and Jin (2002) also find that the estimates in OLS are bigger in magnitude than those in median regression. For example, Aggarwal and Samwick (1999) report that OLS estimates of PPS are more than two times larger than those obtained from the median regression.
} 
Although I have included plenty of controls in the regression, it is still possible that my proxy for hedging cost, Option, is correlated with some unobserved firm characteristics that affect CEO compensation. To address this issue, I add firm fixed effects in Column (3). It is important to note that the inclusion of firm fixed effects can control for any other aspects of the firm that influence the managerial compensation scheme.

The results from the firm fixed effect regression further demonstrate the strong positive association between Option and PPS. The coefficient on Option is around 4 and the corresponding p-value is 0.013. The economic implication of this coefficient is that an increase of Option dummy from zero to one is associated with an increase of PPS by about \$4 per \$1,000 shareholder return, relative to the median PPS of \$7.

In Columns (4)-(6), I replace PPS with $L n(P E I)$ as an alternative measure of the executive incentive and re-do the previous three regressions. ${ }^{7}$ My main results are unchanged: Option dummy has a strongly positive relation with executive incentives measured by PEI. For example, in the fixed effects regression reported in Column (6), the coefficient of Option is 0.1 and is significant at the $1 \%$ level. This coefficient is also economically remarkable since an increase in Option from zero to one is associated with an approximate $10 \%$ increase in PEI. The coefficients on those controls are qualitatively consistent with the findings of Smith and Watts (1992) and Core and Guay (1999). The regression results also indicate that the levels of $P E I$ are well-explained by the regression model outlined earlier. Taking Column (4) for example, the adjusted $\mathrm{R}^{2}$ is $47 \%$, implying that the model explains a substantial proportion of the cross-sectional variation in PEI.

\footnotetext{
${ }^{7}$ The reason that I did not take natural logarithm transform for PPS is to make my result easy to compare with those in prior literature.
} 
Overall, the results in Panel A provide evidence supporting the prediction that the pay-performance sensitivity of management compensation is negatively correlated with the managerial hedging cost.

In Panel B, I use Ln(Volume) as an alternative proxy for the executive hedging cost, and repeat the earlier regression analysis in the previous table. The sample used in this table is a sub-sample, in which the firms have available listed options in the option exchanges. Consistent with the previous panel, Panel B further supports the prediction that the hedging cost is negatively associated with pay-performance sensitivity.

The regression result in Column (1) highlights that the coefficient of $\operatorname{Ln}$ (Volume) is 3.57 and is significant at the $1 \%$ level. This coefficient is also economically meaningful: when Ln(Volume) increases by one standard deviation (1.93), the executive is awarded an increased PPS of $\$ 6.9(3.57 \times 1.93)$ per $\$ 1,000$ shareholder return. Therefore, this result is consistent with the prediction that a lower managerial hedging cost leads to higher stock-based pay sensitivities of CEOs. In the median regression (Column (2)) and fixed effects regression (Column (3)), the coefficients of Option are 1.14 and 6.77, respectively; both of them are significant at the $1 \%$ level.

Columns (4)-(6) in Panel B show that $\operatorname{Ln}($ Volume) also has a significant positive relation with PEI. The coefficients on $\operatorname{Ln}$ (Volume) are $0.11,0.12$ and 0.13 , respectively, implying that a one-standard-deviation increase in $\operatorname{Ln}$ (Volume) predicts an increase in PEI by about 23\% (12\% × 1.93). Other controls have very similar coefficients with those in Panel A.

Since the firms listed in the option exchanges and the ones with large option trading volume are usually large firms, the Option and $\operatorname{Ln}$ (Volume) variables might just capture the 
firm size effect rather than the hedging cost effect. This concern can be ruled out for two reasons. First of all, I have controlled for Firmsize and Firmsize ${ }^{2}$ in the regressions. Therefore, the positive coefficients on Option and Ln(Volume) indicate that firms with publicly tradable options or large option trading volume provide higher CEO incentive than other firms of similar size. I have also used sales volume and total assets to measure firm size instead of market capitalization; the coefficients on the two hedging cost proxies are quite robust. Since Firmsize and Firmsize ${ }^{2}$ are highly correlated, I have also tried to just include either of them in the regressions, and the results on Option and Ln(Volume) are insensitive to these alternative specifications.

Second, the relation between firm size and CEO incentive depends on the measures of incentive pay. I found that firm size is negatively related to PPS but is positively related to PEI; this relation is consistent with prior literature like Core and Guay (1999) and Baker and Hall (1998). However, the coefficients on Option and Ln(Volume) are always significantly positive regardless of whether or not I measure incentive pay by PPS or PEI. This fact further supports the notion that my hedging cost proxies are not capturing firm size effects.

Another concern with my hedging cost proxies is that they might primarily reflect firm risk, as riskier firms are more likely to be listed in option exchanges and to have larger option trading volume (Mayhew and Mihow (2004)). This concern is not valid for the following reasons. First, my regressions have accounted for stock return volatility; the effect of firm risk on incentive pay has been controlled. Second, standard principal-agent theory predicts a negative relation between firm risk and managerial incentive levels (Holmstrom and Milgrom (1987)), which implies that the coefficients on Option and Ln(Volume) would 
be negative if they captured firm risk. Third, as summarized by Prendergast (2002), empirical studies have failed to find any robust association between risk and executive incentive, further indicating that the strong positive relation between hedging cost proxies and incentive compensation is not due to the risk effect on compensation.

The conclusion from Table 2 is clear: CEOs are receiving higher-power compensation contracts when it is less costly for them to hedge their incentive portfolios. This evidence is in support of my theoretical model.

\subsection{Managerial Hedging Cost and Convexity in Incentive Pay}

My earlier analysis on PPS and PEI is about the slope of the relation between the CEO's wealth and stock price. Although managing slope is important in setting CEO pay, another important aspect is the convexity in the compensation package. As is well documented by existing literature like Jensen and Meckling (1976) and Smith and Stulz (1985), the convexity of the relation between stock price and CEO wealth, in addition to the slope, has to be properly designed to induce executives to make optimal corporate decisions. This convexity refers to the sensitivity of executives’ wealth to the volatility of stock return.

As shown by Smith and Stulz (1985), risk-averse managers are likely to forgo risk-increasing but positive net-present-value (NPV) projects, and this risk-related agency problem can be resolved by using stock options to construct a convex relation between executive wealth and firm performance.

Following the framework of Holmstrom and Milgrom (1987) and Guay (1999), the optimal convexity in CEO incentive pay is determined by the benefits of risky positive NPV projects and the cost of compensating the manager for bearing risk. When shareholders 
increase the sensitivity of CEO wealth to firm risk, CEOs are less likely to pass up those risky but value-increasing investments. But shareholders also need to increase the level of total pay to compensate those risk-averse managers for taking risk. In equilibrium, the optimal convexity in CEO pay should decrease in the managerial aversion to risk (Guay (1999) and Coles et al. (2006)). This risk aversion effect depends on the degree of diversification of the manager's wealth portfolio and her utility function. All else equal, good hedging opportunities enable managers to diversify risk and to be less vulnerable to stock price volatility. For this reason, the optimal sensitivity of CEO wealth to firm risk should be higher when managers can hedge more easily.

Like Guay (1999), I define Vega as the change in dollar value of the executive's wealth for a 0.01 change in the annualized standard deviation of stock return. Following Coles et al. (2006), I use Vega of the option portfolio to measure the total Vega of executives' total equity portfolios because option Vega is many times higher than stock Vega. In my sample, the mean and median Vega are $\$ 112.9$ thousand and $\$ 44.5$ thousand, respectively. I regress $\operatorname{Ln}($ vega) on the hedging cost proxies, controlling for potential confounding variables. The regression model is specified below:

$$
\begin{aligned}
& \text { Ln }(\text { Vega })_{i t}=b_{0}+b_{1} \text { Option }_{i t}+b_{2} \text { Ln }\left(\text { Volume }_{i t}+b_{3} \text { FirmSize }_{i t-1}+b_{4} \text { FirmSize }^{2}{ }_{i t-1}\right. \\
& +b_{5} \text { CDF }\left(\text { Variance }_{i t-1}+b_{6} M / B_{i t-1}+b_{7} \text { ROE }_{i t-1}+b_{8} \text { Leverage }_{i t-1}+b_{9} \text { Age }_{i t}+b_{10} \text { Cash }_{i t-1}\right. \\
& +b_{11} \text { Stockreturn }_{i t-1}+\text { IndustryDummy / Firm Fixed Effects }+ \text { YearDummy }+\varepsilon_{i t}
\end{aligned}
$$

Estimating positive coefficients of $b_{1}$ and $b_{2}$ would be consistent with the prediction that the sensitivity of CEO wealth to firm risk is higher when the CEO has better opportunities to hedge her personal portfolio.

\section{[Insert Table 3 Here]}


Table 3 reports a positive relation between $\operatorname{Ln}(V e g a)$ and the hedging cost proxies; the relation is both statistically and economically significant. Taking Column (1) for example, I use the Option variable as the proxy for the hedging cost and run pooled OLS regression. The coefficient on Option is 0.17 and is significant at the $1 \%$ level. This result indicates that a zero-to-one increase in Option is associated with approximately $17 \%$ increase in Vega. Taking Column (6) for another example, I use Ln(Volume) to proxy for the hedging costs in the firm fixed effect regression; the coefficient on $\operatorname{Ln}$ (Volume) is 0.07 and is statistically significant at the $1 \%$ level. The result is quite economically important; Vega will increase by about $13.5 \%$ when Ln(Volume) increases by one standard deviation.

As suggested by Coles et al. (2006), the slope and convexity in the CEO's compensation contract are jointly determined. In other words, shareholders choose a combination of the slope and the convexity to solve the compensation problem optimally. In this case, using simultaneous equations to estimate PPS/PEI and Vega jointly could be a more appropriate approach than estimating them separately. Following Coles et al. (2006), I use three-stage least squares (3SLS) to estimate the following simultaneous equations:

$$
\begin{aligned}
& \operatorname{Ln}(\text { Vega })_{i t}=\gamma_{0}+\gamma_{1} \operatorname{Ln}(P E I)_{i t}+\gamma_{2} \text { Option }_{i t}+\gamma_{3} \operatorname{Ln}\left(\text { Volume }_{i t}+\gamma_{4} \text { FirmSize }_{i t-1}\right. \\
& \left.+\gamma_{5} \text { FirmSize }_{i t-1}^{2}+\gamma_{6} \text { CDF(Variance }\right)_{i t-1}+\gamma_{7} M / B_{i t-1}+\gamma_{8} R O E_{i t-1}+\gamma_{9} \text { Leverage }_{i t-1} \\
& +\gamma_{10} \text { Cash }_{i t-1}+\gamma_{11} \text { Stockreturn }_{i t-1}+\gamma_{12} \text { Ln }_{\text {(Cash Compensation })_{i t}}+\text { IndustryDummy } \\
& + \text { YearDummy }+\varepsilon_{i t} \\
& \operatorname{Ln}(\text { PEI })_{i t}=\delta_{0}+\delta_{1} \operatorname{Ln}(\text { Vega })_{i t}+\delta_{2} \text { Option }_{i t}+\delta_{3} \operatorname{Ln}\left(\text { Volume }_{i t}+\delta_{4} \text { FirmSize }_{i t-1}\right. \\
& +\delta_{5} \text { FirmSize }_{i t-1}^{2}+\delta_{6} C D F(\text { Variance })_{i t-1}+\delta_{7} M / B_{i t-1}+\delta_{8} R O E_{i t-1}+\delta_{9} \text { Leverage }_{i t-1} \\
& \delta_{10} \text { Age }_{i t}+\gamma_{11} \text { Cash }_{i t-1}+\gamma_{12} \text { Stockreturn }_{i t-1}+\text { IndustryDummy } \text { YearDummy } \varepsilon_{i t}
\end{aligned}
$$

\section{[Insert Table 4 Here]}

Table 4 contains the system's specifications using two hedging cost proxies. In each case, the jointly determined variables are Vega and PEI. The independent variables are 
generally drawn from the prior literature like Guay (1999) and Coles et al. (2006). The variable Cash Compensation is the 2000 dollar value of the CEO’s cash pay.

The coefficients on Option and Ln(Volume) are positive and both economically and statistically significant. This result supports the fact that shareholders increase both the slope and convexity in the CEO's incentive pay when the CEO has good hedging opportunities. In Columns (1) and (2), the coefficients on Option are about 0.16 and 0.06 , respectively, and both are significant at the $5 \%$ level. Controlling for other factors, a firm with publicly-tradable options provides about 16\% higher Vega and 6\% higher PEI than a company without such options. I then use Ln(Volume) as an alternative proxy for hedging costs in Columns (3) and (4). The corresponding coefficients are 0.16 and 0.12, respectively, and both are significant at the $1 \%$ level. A one-standard-deviation increase in Ln(Volume) is associated with 31\% increase in Vega and 23\% increase in PEI.

Other control variables are generally consistent with the results in Coles et al. (2006). I also replace $L n(P E I)$ with $P P S$ in the systems and find that the coefficients on Option and Ln(Volume) do not change qualitatively. The simultaneous equations results for PPS are omitted here for brevity.

In summary, the evidence in Tables 3 and 4 supports the view that higher executive hedging costs are associated with not only lower pay-performance sensitivity but also lower sensitivity of CEO wealth to equity volatility.

\subsection{Managerial Hedging Cost and Capital Structure}

Given the fact that managerial hedging undermines the efficacy of incentive contracts, how will shareholders use other mechanism to resolve the executive incentive problem? 
This section addresses the above problem by examining the impact of executive hedging on the firm's capital structure.

Agency theory suggests that debt mitigates shareholder-manager agency problem by inducing lenders to monitor, reducing the free cash flow available to managers, and forcing managers to maximize value when facing the threat of bankruptcy (Jensen (1986) and Stulz (1990)). For this reason, Ortiz-Molina (2007) suggests that high leverage and high-power incentive contracts can be substitutes. In a theoretical model in which shareholders set both capital structure and compensation policy to discipline managers, Garvey (1997) shows that debt is important in aligning shareholder-manager interests, especially when managers can unload their incentive contracts in a liquid secondary market. In one word, the literature on capital structure and agency problem implies that firms should experience higher debt level when their managers have better opportunities to hedge incentive pay. ${ }^{8}$ To empirically examine this prediction, I run pooled OLS regressions using the model below:

$$
\begin{aligned}
& \text { Leverage }_{i t}=c_{0}+c_{1} \text { Option }_{i t}+c_{2} \text { Ln }(\text { Volume })_{i t}+c_{3} \text { FirmSize }_{i t-1}+C_{4} \text { StockReturn }_{i t-1} \\
& +c_{5} \text { CDF }(\text { Variance })_{i t-1}+c_{6} M / B_{i t-1}+c_{7} R \text { OE } E_{i t-1}+c_{8} \text { Tangibility }_{i t-1}+c_{9} R \& D_{i t-1} \\
& +c_{10} \text { Advertising }_{i t-1}+\text { IndustryDummy }+ \text { YearDummy }+\varepsilon_{i t}
\end{aligned}
$$

Here, the dependent variable is the firm's leverage ratio, measured by both the book leverage and market leverage. Book leverage follows the same definition with Leverage defined in Section 4.3; market leverage is computed as the book value of long-term debt / (book value of long-term debt + market value of equity). The variable Tangibility is the ratio of the firm's fixed assets over total assets; $R \& D$ is the ratio of $R \& D$ expenses to sales; Advertising is the firm's advertising expenses over sales. Since I no longer require data

\footnotetext{
8 Although it could be the managers who make the capital structure decision, the board and shareholders do have strong influence on the financing decision (see, e.g., Guner et al. (2008) and Klein (1998)).
} 
availability in ExecuComp, my sample size for analyzing capital structure increases to 59,381 firm-year observations from 1996 to 2005. Among them, 17,638 observations have their options traded in option exchanges. Available studies agree that capital structures are influenced by the factors like firm size, asset tangibility, growth opportunities, advertising expenditure, R\&D expenditure, volatility and profitability (Harris and Raviv (1991)). Estimating positive coefficients of $c_{1}$ and $c_{2}$ would be consistent with the prediction that financial leverage level is negatively associated with the executive hedging cost.

\section{[Insert Table 5 Here]}

Table 5 highlights the hedging cost as a strong determinant for capital structure decisions. In Column (1), I regress book leverage on the Option dummy as well as control variables. The coefficient on Option is 2.19 and significant at the $1 \%$ level. The zero-to-one increase in Option is associated with an increase in book leverage by about 2.2 percentage points, relative to the sample median of $9 \%$. Then I replace Option with Ln(Volume) in Column (2). The coefficient of $\operatorname{Ln}$ (Volume) is 0.74 and significant at the $1 \%$ level. Again, the economic impact is sizeable; book leverage will increase by about 1.4 percentage points when $\operatorname{Ln}$ (Volume) increases by one standard deviation.

Next, I use market leverage as the dependent variable and repeat the regression analysis in Columns (3) and (4). Both Option and Ln(Volume) attract positive coefficients, and the coefficients are economically and statistically significant. Taking Column (3) for example, the variable Option has a significant coefficient of 1.04, implying an increase in market leverage of 1.04 percentage points when Option changes from zero to one. Considering that the sample median of market leverage is $6 \%$, this result is certainly remarkable. Among the 
control variables, the coefficients on $C D F$ (Variance) and $M / B$ are persistently negative across all of the four regressions, indicating risky firms and high-growth firms are using less debt. The variable Tangibility is significantly positively associated with the leverage level.

The regression analysis in Table 5 supports the prediction that shareholders tend to use more debt when managers have better opportunities to hedge. This result also implies that, besides providing higher-power contracts, shareholders simultaneously use other mechanisms like capital structure to resolve shareholder-manager agency problem as responding to executive hedging.

\subsection{Managerial Hedging Cost and Option Exercising/Holding Behavior}

Although I argue that liquid public option trading can help executives to hedge their incentive portfolios, there is a lack of direct evidence on this conjecture. ${ }^{9}$ To further support that the two hedging cost proxies do influence CEOs' hedging behavior, I investigate executive option exercising/holding behavior in this section.

CEOs usually receive large grants of stock and options of their own firms as compensation, and in the mean time their human capital is also intimately linked to the firms' performance. As they are usually prevented from unwinding their options or stock, these under-diversified and risk-averse CEOs should be eager to exercise their in-the-money options when the vesting period expires (Hall and Murphy (2000) and (2002)). As argued by Malmendier and Tate (2005), those CEOs should minimize their holdings of company equity in order to divest themselves of idiosyncratic risk. However, ceteris paribus, when CEOs can hedge their equity positions to a certain extent, they will be less eager to exercise

\footnotetext{
${ }^{9}$ Ideally, I would like to see managers' personal transactions in the equity/derivative market. However, this kind of data is unfortunately unavailable.
} 
their vested options, and will tend to hold more exercisable in-the-money options, simply because the firm-specific risk can be diversified away through the hedging instruments. There are two reasons why CEOs should hedge and keep exercisable options instead of exercising them directly. First, direct option exercising would send negative signals to investors. If managers fear this signal, they may retain their options while taking some hedging positions. Second, the market value of a "live" option usually exceeds the proceeds from exercise; managers face the tradeoff between diversification benefits and cost of early exercise. When managers can use hedging instruments, like put options, to protect themselves from stock price downturn, they will keep their exercisable options alive.

To test this prediction, I use five variables to measure a CEO's holding of in-the-money exercisable options. They are (1) dollar value of the CEO’s exercisable in-the-money option in 2000-constant dollars (Opt1), (2) Opt1 as a percentage of the CEO's total annual compensation (Opt2), (3) Opt1 as a percentage of the firm's stock capitalization (Opt3), (4) number of common shares that the CEO's exercisable in-the-money option is writing on as a percentage of the firm's stock shares already owned by the CEO (Opt4), and (5) number of common shares that the CEO's exercisable in-the-money option is writing on as a percentage of the firm's total shares outstanding (Opt5).

I run pooled OLS regressions using the following model

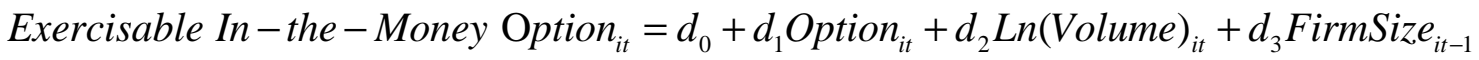
$+d_{4} C D F(\text { Variance })_{i t-1}+d_{5}$ Ownership $_{i t-1}+d_{6} M / B_{i t-1}+d_{7}$ Age $_{i t}+d_{8}$ StockReturn $_{i t}$ + IndustryDummy + YearDummy $+\varepsilon_{i t}$

Existing literature suggests a few important variables that may influence managers' option exercising/holding behavior, including firm size, managerial ownership, stock return 
volatility, growth opportunities, managerial risk-aversion, and recent stock movement. ${ }^{10}$ The Ownership variable measures the percentage of the firm's shares owned by the CEO. Based on the implication that a manager with lower hedging costs will hold more vested in-the-money options, I would expect the coefficients $d_{1}$ and $d_{2}$ to be positive.

\section{[Insert Table 6 Here]}

Panel A of Table 6 highlights a positive association between the Option dummy and executives' exercisable in-the-money options. The dependent variable in Model (1) is $\operatorname{Ln}(1+$ Opt1), the coefficient on Option is 0.4 with the p-value less than 0.001 . The economic magnitude is quite large; as Option increases from zero to one, the dollar value of managers' holding of vested in-the-money options will increase by $40 \%$. I normalize the dollar value of options by the CEO's total annual compensation, and use $\operatorname{Ln}(1+O p t 2)$ as the left-hand variable in Regression (2). The variable Option has a positive coefficient of 0.22 , which is significant at the $1 \%$ level. As another alternative specification, I include $\operatorname{Ln}(1+O p t 3)$ as the explained variable in Column (3), where the firm's stock capitalization is the deflator. The Option dummy still has a significant and positive coefficient of 0.028 .

To further examine the robustness of my results, I employ the shares of vested in-the-money options instead of dollar values. The predicted variable in Model (4) is $\operatorname{Ln}(1+$ Opt4); the coefficient on Option is 0.095 and significant at the $5 \%$ level, indicating that a zero-to-one increase of Option is associated with $9.5 \%$ increase of Opt4. Finally, I scale the option numbers by the firm's total shares outstanding, and use $\operatorname{Ln}(1+O p t 5)$ in Column (5). Consistent with the previous four models, the coefficient on Option is positive and both

${ }^{10}$ See Ofek and Yermack (2000), and Huddart and Lang (1996). 
statistically and economically significant.

Panel B provides further regression results supporting the expected relation between executive option holding and the hedging cost, using $\operatorname{Ln}($ Volume) as the proxy. All of the five regressions (except Model (2)) highlight a significantly positive relation between Ln(Volume) and executives' holding of exercisable in-the-money options. The conclusion from Table 6 is quite clear. Managers are less eager to unwind their equity portfolios when they can access hedging instruments more easily. The finding also supports the claim that the two variables, Option and Ln(Volume), capture the effect of managerial hedging cost and influence managers’ hedging behavior.

\subsection{Managerial Hedging Cost and Corporate Dividend Policy}

In earlier analysis of this paper, I mainly focus on how shareholders design compensation in response to executive hedging. A natural question for extension is how the hedging influences managers’ decisions on corporate policies, such as investment, financing policy, dividend policy and other related policy decisions. In this section, I examine the effect of executive hedging cost on corporate dividend payments. ${ }^{11}$

Executive stock options furnish management with the incentive to reduce dividends because the value of executive stock options, like all call options, are negatively related to future dividend payments. Consistent with this hypothesis, Lambert et al. (1989) document that dividends are reduced relative to expected levels following the adoption of executive stock option plans. Fenn and Liang (2001) further report a strong negative relationship between dividends and management stock options. However, in the presence of managerial

\footnotetext{
${ }^{11}$ I leave the investigation on other corporate policies for future research.
} 
hedging, managers will not have such a strong incentive to cut dividends, simply because paying dividend will have less of a negative effect on their personal wealth. To test this view, I run pooled OLS regressions using the following model:

Dividend $_{i t+1}=e_{0}+e_{1}$ Optionpay $_{i t}+e_{2}$ Ln(Optionwealth $_{i t}+e_{3}$ Option $_{i t} \times$ Optionpay $_{i t}+$ $e_{4}$ Option $_{i t} \times \operatorname{Ln}(\text { Optionwealth })_{i t}+e_{5} \operatorname{Ln}\left(\right.$ Volume $_{i t} \times$ Optionpay $_{i t}+e_{6} \operatorname{Ln}\left(\right.$ Volume $_{i t} \times \operatorname{Ln}(\text { Optionwealth })_{i t}$ $+e_{7}$ Option $_{i t}+e_{8} \operatorname{Ln}\left(\right.$ Volume $_{i t}+e_{9}$ Firmsize $_{i t}+e_{10} C D F(\text { Variance })_{i t}+e_{11} M / B_{i t}+e_{12} R O E_{i t}$ $+e_{13}$ Leverage $_{i t}+e_{14}$ Cash $_{i t}+$ IndustryDummy + YearDummy $+\varepsilon_{i t+1}$

Here, the dependent variable is the firm's dividend payment (Compustat Item 21) normalized by stock market capitalization. The variable, Optionpay, is the value of the CEO's annual option grants as a proportion of her total annual compensation; Optionwealth is the Balck-Scholes value of the CEO's total holding of stock options. Obviously, Optionpay is a flow variable, and Optionwealth is a level variable. I use these two variables to measure the relative importance of stock options for a CEO's wealth. I expect the $e_{1}$ and $e_{2}$ coefficients to be negative, and the $e_{3}, e_{4}, e_{5}$ and $e_{6}$ coefficients to be positive. Since my compensation data is from 1996 to 2005, the dividend data used in the regressions is from 1997 to 2006. The sample in this regression consists of 17,036 firm-year observations; 11,247 observations have their options listed on option exchanges.

\section{[Insert Table 7 Here]}

Table 7 reports the results of estimating the above equation, in which I regress corporate dividend payments on the control variables plus CEOs' option holding, as well as the latter's interaction with the hedging cost proxies. In Column (1), I use the Option dummy to measure the hedging cost, and Optionpay for the CEO's option pay. The coefficient of Optionpay is significantly negative. The interaction term, Option XOptionpay, has a significantly positive coefficient. 
I replace Optionpay with Ln(Optionwealth) in Column (2). Similar to Column (1), I find a negative coefficient on $\operatorname{Ln}$ (Optionwealth), and a positive coefficient on Option $X$ Ln(Optionwealth). Both of the coefficients are significant at the $1 \%$ level. Furthermore, I substitute Option with Ln(Volume) in Columns (3)-(4), repeat the previous two regressions, and find qualitatively similar results. The interactions, Ln(Volume) $\times$ Optionpay and Ln(Volume) $\times \operatorname{Ln}($ Optionwealth), are positive; both Optionpay and Ln(Optionwealth) have significantly negative coefficients.

Those coefficients of the interaction terms are economically significant as well. Taking Model (1) for example, Optionpay and Option XOptionpay have the coefficients of -1.22 and 0.71 , respectively. The interpretation of this result is as follows. When Option $=0$, the partial effect of Optionpay on dividend payment is -1.22 ; when Option=1, the partial effect of Optionpay is reduced to $-0.51(-1.22+0.71=-0.51)$.

The regression analysis in Table 7 supports the prediction that managerial hedging weakens the negative relation between management option pay and corporate dividends. The result is also consistent with a broader idea that managers who can hedge are less influenced by their incentive pay.

\subsection{Managerial Hedging Cost and Corporate Diversification}

In addition to hedging personal incentive portfolios, another way for managers to hedge risk is to diversify their companies. This section addresses the natural question of how managerial hedging costs influence corporate diversification.

Existing literature has found risk reduction as a strong motive for corporate diversification (Amihud and Lev (1981) and May (1995)). Managers typically have large, 
undiversified positions in their own firms. To the extent that diversification decreases firm risk, managers facing higher idiosyncratic risk tend to diversify the companies more to lower the risk. Given that managerial hedging enables the managers to unwind their wealth from firm risk, I expect that diversifying both personal portfolios and firms are substitutes for managers to reduce risk. In other word, when executives can hedge their incentive pay more easily, they will execute fewer corporate diversification initiatives. Testing this prediction empirically, I run pooled OLS regressions estimating the following model:

$$
\begin{aligned}
& \text { CorporateDiversification }_{i t}=f_{0}+f_{1} \text { Option }_{i t}+f_{2} \operatorname{Ln}\left(\text { Volume }_{i t}+f_{3} \text { FirmSize }_{i t-1}\right. \\
& +f_{4} \text { StockReturn }_{i t-1}+f_{5} \text { CDF }(\text { Variance })_{i t-1}+f_{6} M / B_{i t-1}+f_{7} R E_{i t-1}+f_{8} \text { Cash }_{i t-1} \\
& + \text { IndustryDummy }+ \text { YearDummy }+\varepsilon_{i t}
\end{aligned}
$$

I use two measures of corporate diversification, the Herfindahl index of the concentration of sales across the various business segments and the number of reported business segments. A more diversified firm is represented by a lower value of Herfindahl Index and more segments. The regression sample consists of 52,472 firm-year observations from 1996 to 2005; 16,369 observations have options traded in the option exchanges. The means of Herfindahl Index and segment number are 0.83 and 2.01, respectively. To support the prediction that corporate diversification is positively associated with managerial hedging costs, I would expect positive (negative) coefficients for $f_{1}$ and $f_{2}$ when Herfindahl Index (segment number) is the dependent variable.

\section{[Insert Table 8 Here]}

Table 8 highlights the significantly positive relation between the degree of corporate diversification and executive hedging costs. In Columns (1) and (2), the dependent variable is Herfindahl Index. The coefficients on Option and Ln(Volume) are 0.017 and 0.004 , 
respectively; both are significant at the $10 \%$ level. These positive coefficients indicate that low hedging costs are associated with higher Herfindahl Index (less firm diversification). I then replace Herfindahl Index with the natural logarithm of segment number as the dependent variable in Columns (3) and (4). The results are qualitatively similar. Other controls are generally consistent with those in Coles et al. (2006) and Berger and Ofek (1999). In summary, the regression analysis supports the prediction that when managers can hedge their incentive pay, they initiate fewer diversification projects with their companies.

\section{Conclusion}

This paper examines the optimal executive compensation with respect to managerial hedging. The driving force behind my theoretical analysis is the notion that an executive's actions are influenced by the cost for her to access hedging instruments. I extend previous research by showing that the hedging cost has important effects on the manager's effort-exerting incentive and risk-bearing ability. My model predicts a negative association between pay-performance sensitivity and the managerial hedging cost. I then provide empirical evidence supporting the model's prediction.

Two variables are employed to measure the hedging cost. The first measure is a dummy variable indicating the availability of the firm's options on option exchanges. I then use the firm's option trading volume as the second proxy. In a straightforward manner, these two variables capture the ease with which one can trade the firm's derivatives in order to hedge idiosyncratic risk. Equivalently, the two proxies reflect the opportunities that managers have to make the hedging transactions.

In addition to examining the pay-performance sensitivity, I also investigate the impact 
of managerial hedging on the sensitivity of CEO wealth to stock volatility. My findings support the view that shareholders should increase the convexity of the relation between CEO wealth and stock return, along with increasing the slope, when managers can hedge.

To deepen my understanding of the managerial hedging problem, I then examine whether shareholders use other mechanism to resolve this hedging issue, in addition to offering high-power contracts. Particularly, I address this question by investigating the capital structure decision. As a substitute for incentive pay, debt is widely suggested by available studies as a powerful way to align shareholder-manager interests. When executive hedging undermines the effectiveness of incentive compensation, shareholders are expected to increase financial leverage as an alternative way to restore executive incentive. Consistent with this argument, I document evidence that firms exhibit higher leverage ratios when it is easier for their managers to unwind the incentive contracts.

To validate that the two proxies measure the hedging cost and influence managers' personal trading, I further analyze executives’ option exercising/holding behavior. Existing studies suggest that managers will hold more exercisable in-the-money options when they can diversify firm-specific risk through hedging instruments. Consistent with this prediction, my analysis documents a negative relation between the hedging cost and holdings of options that have become vested and in-the-money.

Furthermore, I extend my study by investigating how managerial hedging influences corporate policies. In particular, I look at corporate dividend payouts. Prior research shows that option pay induces managers to cut dividend payments. Based on the idea that managers who can hedge are less influenced by their incentive portfolios, managerial 
hedging is expected to undermine the negative association between option compensation and dividend payments. I then provide evidence supporting this implication.

Last but not least, to the extent that diversifying the firm and hedging personal portfolios are substitutes for managers to reduce risk, I document evidence that managers undergo fewer corporate diversification initiatives when they have lower costs to hedge their incentive pay.

In summary, my study concludes five major implications that (1) managerial hedging undermines managers' incentive to exert effort and increases their ability to bear risk, (2) shareholders enhance both the sensitivity and convexity of the relation between CEO wealth and stock return in corresponding compensation contracts, (3) shareholders adopt higher financial leverage to overcome this executive-hedging issue in addition to providing higher-power contracts, (4) managerial hedging significantly influences a manager's behavior of rebalancing her personal portfolio and her decisions on paying dividends, and (5) managers diversify their firms less when they can hedge their incentive pay more easily. Finally, this paper provides indirect evidence that managers tend to use public options markets to undo their incentive compensation. 


\section{Reference}

Acharya, V. V., and A. Bisin, 2005, Managerial hedging, equity ownership, and firm value, London Business School working paper.

Aggarwal, R., and A. Samwick, 1999, The other side of the trade-off: The impact of risk on executive compensation, Journal of Political Economy 10, 65-105.

Aggarwal, R., and A. Samwick, 2003, Why do managers diversify their firms? Agency reconsidered, Journal of Finance 58, 71-118.

Amihud, Y., and B. Lev, 1981, Risk reduction as a managerial motive for conglomerate mergers, Bell Journal of Economics 12, 605-617.

Antle, R., and A. Smith, 1986, An empirical examination of relative performance evaluation of corporate executives, Journal of Accounting Research 24, 1-39.

Baker, P. G., and J. B. Hall, 2004, CEO incentives and firm size, Journal of Labor Economics 22, 767-798.

Bebchuk, L.A., J. M. Fried, and D. I. Walker, 2002, Managerial power and rent extraction in the design of executive compensation, University of Chicago Law Review 69, 751-846.

Bettis, J. C., J. M. Bizjak,, and M. L. Lemmon, 2001, Managerial ownership, incentive contracting, and the use of zero-cost collars and equity swaps by corporate insiders, Journal of Financial and Quantitative Analysis 36, 345-370.

Berger, P., and E. Ofek, 1999, Causes and effects of corporate refocusing programs, Review of Financial Studies 12, 311-345.

Bisin, A., P. Gottardi, and A. A. Rampini, 2006, Managerial hedging and portfolio monitoring, New York University working paper.

Black, F., and M. Scholes, 1973, The pricing of options and corporate liabilities, Journal of Political Economy 81, 637-659.

Breen, W. J., L. S. Hodrick, and R. A. Korajczyk, 2002, Predicting equity liquidity, Management Science 48, 470-483.

Coles, J. L., N. D. Daniel, and L. Naveen, 2006, Managerial incentives and risk-taking, Journal of Financial Economics 79, 431-468.

Core, J., and W. Guay, 1999, The use of equity grants to manage optimal equity incentive levels, Journal of Accounting and Economics 28, 151-184. 
Core, J., and W. Guay, 2002, Estimating the value of employee stock option portfolios and their sensitivities to price and volatility, Journal of Accounting Research 40, 613-630.

Economist, 1999, Share options: Executive relief, April 3.

Fama, E., and K. French, 1997, Industry costs of capital, Journal of Financial Economics 43, 153-193.

Fenn, G. W., and N. Liang, 2001, Corporate payout policy and managerial stock incentives, Journal of Financial Economics 60, 45-72.

Garvey, G., 1997, Marketable incentive contracts and capital structure relevance, Journal of Finance 52, 353-378.

Garvey, G., and T. Milbourn, 2003, Incentive compensation when executives can hedge the market: Evidence of relative performance evaluation in the cross section, Journal of Finance 58, 1557-1582.

Gibbons, R., and K. J. Murphy, 1992, Optimal incentive contracts in the presence of career concerns: Theory and evidence, Journal of Political Economy 100, 468-505.

Guay, W. R., 1999, The sensitivity of CEO wealth to equity risk: An analysis of the magnitude and determinant, Journal of Financial Economics 53, 43-71.

Guner, B., G. Tate, and U. Malmendier, 2008, Financial expertise of directors, Journal of Financial Economics 88, 323-354.

Hall, B. J., and J. Liebman, 1998, Are CEOs really paid like bureaucrats?, The Quarterly Journal of Economics 103, 653-691.

Hall, B. J., and K. J. Murphy, 2000, Optimal exercise prices for executive stock options, American Economic Review 90, 209-214.

Hall, B. J., and K. J. Murphy, 2002, Stock options for undiversified executives, Journal of Accounting and Economics 33, 3-42.

Harris, M., and A. Raviv, 1991, The theory of capital structure, Journal of Finance 46, 297-356.

Holmstrom, B., and P. Milgrom, 1987, Aggregation and linearity in the provision of intertemporal incentives, Econometrica 55, 303-328.

Huddart, S., and M. Lang, 1996, Employee stock option exercises: An empirical analysis, Journal of Accounting and Economics 21, 5-43. 
Ip, G., 1997, Collars give insiders way to cut risk, Wall Street Journal, September 17.

Jensen, M., 1986, Agency cost of free cash-flow, corporate finance, and takeovers, American Economic Review 76, 323-329.

Jensen, M., and W. Meckling, 1976, Theory of the firm: managerial behavior, agency costs, and ownership structure, Journal of Financial Economics 3, 305-360.

Jensen, M., and K. Murphy, 1990, Performance pay and top management incentives, Journal of Political Economy 98, 225-264.

Jin, L., 2002, CEO compensation, diversification, and incentives, Journal of Financial Economics 66, 29-63.

John, T. A., and K. John, 1993, Top management compensation and capital structure, Journal of Finance 48, 949-974.

Klein, A., 1998, Firm performance and board committee structure, Journal of Law and Economics 41, 275-303.

Korajczyk, R. A., and R. Sadka, 2004, Are momentum profits robust to trading costs?, Journal of Finance 59, 1039-1082.

Lambert, R.A., W.N. Lanen, and D.F. Larcker, 1989, Executive stock option plans and corporate dividend policy. Journal of Financial and Quantitative Analysis 24, 409-425.

Lavelle, L., 2001, Undermining pay performance, Business Week 15, 70-71.

Malmendier, U., and G. Tate, 2005, CEO overconfidence and corporate investment, Journal of Finance 60, 2661-2700.

May, D., 1995, Do managerial motives influence firm risk reduction strategies?, Journal of Finance 50, 1291-1308.

Mayhew, S., and V. Mihov, 2004, How do exchanges select stocks for option listing?, Journal of Finance 59, 447-471.

Merton, R., 1973, Theory of rational option pricing, Bell Journal of Economics and Management Science 4, 141-183.

Milbourn, T. T., 2003, CEO reputation and stock-based compensation, Journal of Financial Economics 68, 233-262.

Muelbroek, L. K., 1992, An empirical analysis of illegal insider trading, Journal of Finance 
7, 1661-1701.

Ofek, E., and D. Yermack, 2000, Taking stock: Equity-based compensation and the evolution of managerial ownership, Journal of Finance 55, 1367-1384.

Ortiz-Molina, H., 2007, Executive compensation and capital structure: The effect of convertible debt and straight debt, Journal of Accounting and Economics forthcoming.

Ozerturk, S., 2006, Financial innovations and managerial incentive contracting, Canadian Journal of Economics 39, 434-454.

Prendergast, C., 2002, The tenuous trade-off between risk and incentives, Journal of Political Economy 110, 1071-1102.

Puri, S., 1997, New tools for the options crowd, Fortune, November 10.

Schizer, D. M., 2000, Executives and hedging: The fragile legal foundation of incentive compatibility, Columbia Law Review 100, 440-504.

Simon, R., 2000, Hedging a single stock as ups, downs, Wall Street Journal, February 2.

Smith, C., and R. Stulz, 1985, The determinants of firm's hedging policies, Journal of Financial and Quantitative Analysis 20, 391-405.

Smith, C., and R. Watts, 1992, The investment opportunity set and corporate financing, dividends, and compensation policies, Journal of Financial Economics 32, 263-292.

Stulz, R., 1984, Optimal hedging policies, Journal of Financial and Quantitative Analysis 19, 127-140.

Stulz, R., 1990, Managerial discretion and optimal financing policies, Journal of Financial Economics 7, 117-161.

Yermack, D., 1995, Do corporations award CEO stock options effectively? Journal of Financial Economics 39, 237-269. 


\section{Table 1. Descriptive Statistic of Sample Firms}

\section{Panel A: Descriptive Statistic of Firm Characteristics}

The sample consists of 13,691 firm-year observations from 1996 to 2005. In the sample, 10,123 firm-year observations have their options traded on U.S. option exchanges. I obtain stock price data in CRSP, accounting data in Compustat, CEO compensation data in ExecuComp, and option trading data in OptionMetrics. MV Equity (\$million) refers to the market capitalization of the equity. ROE is the accounting return of equity, obtained as the ratio of earnings before interest and taxes to book value of common equity. Leverage is the ratio of long-term debt (book value) over total assets. M/B is the ratio of market value of equity over book value of equity. Variance is the stock return variance based on the monthly return of past five years. Cash is the ratio of cash plus short-term investment over total assets. Stockreturn is the firm's annual stock return. Option is a dummy variable which equals to one if the firm's option is traded on U.S. option exchanges, and zero otherwise. Volume is the average number of daily option contracts traded. PPS is calculated as the dollar value change of the stock and options held by a CEO for per $\$ 1,000$ shareholders return. PEI (\$thousand) is the sensitivity of the total value of stock and options held by a CEO to $1 \%$ change in stock price. $\operatorname{Ln}()$ denotes the natural logarithm transform. All the dollar-value variables are measured in 2000-constant dollars.

\begin{tabular}{lccccc}
\hline & Mean & Std & $5^{\text {th }}$ Pct & Median & $95^{\text {th }}$ Pct \\
\hline MV Equity & 4814 & 10424 & 153 & 1339 & 20796 \\
ROE & $10 \%$ & $20 \%$ & $-17 \%$ & $12 \%$ & $31 \%$ \\
Leverage & $19 \%$ & $18 \%$ & 0 & $17 \%$ & $49 \%$ \\
M/B & 2.93 & 2.62 & 0.73 & 2.14 & 7.95 \\
Variance*100 & 1.77 & 1.67 & 0.34 & 1.17 & 5.35 \\
Age & 55.76 & 6.9 & 44 & 56 & 67 \\
Cash & 0.12 & 0.16 & 0 & 0.05 & 0.49 \\
Stockreturn & $6.5 \%$ & $47 \%$ & $-78 \%$ & $10.5 \%$ & $76 \%$ \\
Option & 0.74 & 0.44 & 0 & 1 & 1 \\
Volume & 990 & 2554 & 7 & 139 & 5153 \\
Ln(Volume) & 5.09 & 1.93 & 2.12 & 4.94 & 8.55 \\
PPS & 26.08 & 51.56 & 0.73 & 6.96 & 138.69 \\
PEI & 388.9 & 978.37 & 5.87 & 112.2 & 1569.73 \\
\hline
\end{tabular}




\section{Panel B: Correlation Matrix of Explanatory Variables}

The sample consists of 13,691 firm-year observations from 1996 to 2005. Variables used in this matrix are defined in Panel A. Correlations with an absolute value greater than 0.03 are significant at the 5\% level.

\begin{tabular}{lccccccccccc}
\hline & $(1)$ & $(2)$ & $(3)$ & $(4)$ & $(5)$ & $(6)$ & $(7)$ & $(8)$ & (9) & (10) & (11) \\
(1) Option & 1 & & & & & & & & & & \\
(2) Ln(Volume) & - & 1 & & & & & & & & & \\
(3) FirmSize & 0.34 & 0.58 & 1 & & & & & & & & \\
(4) FirmSize & 0.30 & 0.59 & 0.89 & 1 & & & & & & & \\
(5) Variance & 0.09 & 0.18 & -0.38 & -0.28 & 1 & & & & & & \\
(6) M/B & 0.15 & 0.26 & 0.24 & 0.27 & 0.18 & 1 & & & & & \\
(7) ROE & 0.06 & 0.02 & 0.26 & 0.24 & -0.39 & 0.12 & 1 & & & & \\
(8) Leverage & -0.02 & 0.00 & 0.12 & 0.08 & -0.19 & -0.11 & -0.05 & 1 & & & \\
(9) Age & -0.03 & -0.04 & 0.10 & 0.07 & -0.23 & -0.10 & 0.08 & 0.06 & 1 & & \\
(10) Cash & 0.11 & 0.19 & -0.18 & -0.10 & 0.52 & 0.29 & -0.14 & -0.43 & -0.16 & 1 & \\
(11)Stockreturn & -0.02 & 0.00 & -0.06 & -0.06 & -0.14 & -0.08 & 0.06 & -0.02 & 0.02 & -0.03 & 1 \\
\hline
\end{tabular}


Table 2. Managerial Hedging Cost and Pay-performance Sensitivity

\section{Panel A: Using Option Dummy as the Proxy for Hedging Cost}

The sample consists of 13,314 firm-year observations from 1996 to 2005. In the sample, 10,123 firm-year observations have their options traded on U.S. option exchanges. Pay-performance sensitivity (PPS) is calculated as the dollar value change of the stock and options held by a CEO for per $\$ 1,000$ shareholders return. Portfolio equity incentive (PEI) is the sensitivity of the total value of stock and options held by a CEO to $1 \%$ change in stock price, and PEI is measured in \$thousand. Option is a dummy variable which equals to one if the firm's option is traded on U.S. option exchanges, and zero otherwise. $\operatorname{Ln}()$ denotes the natural logarithm transform. Industry dummies are constructed based on Fama and French (1997)'s 48 industries. Corresponding p-values are reported in brackets. The p-values for OLS regressions are based on robust standard errors clustered at the firm level. The p-values for median regressions are according to bootstrapped standard errors based on 20 replications. The notation ***, ** and * denote statistical significance at the $1 \%, 5 \%$ and $10 \%$ level, respectively.

\begin{tabular}{|c|c|c|c|c|c|c|}
\hline & (1) & (2) & (3) & (4) & (5) & (6) \\
\hline & $P P S$ & $P P S$ & PPS & $\operatorname{Ln}(P E I)$ & $\operatorname{Ln}(P E I)$ & $\operatorname{Ln}(P E I)$ \\
\hline & OLS & Median & Fixed Effect & OLS & Median & Fixed Effect \\
\hline \multirow{2}{*}{ Option } & $3.21 * * *$ & $0.76 * * *$ & $4.07 * *$ & $0.35 * * *$ & $0.11 * * *$ & $0.1 * * *$ \\
\hline & {$[0.000]$} & {$[0.005]$} & {$[0.013]$} & {$[0.000]$} & {$[0.000]$} & {$[0.000]$} \\
\hline \multirow{2}{*}{ FirmSize } & $-26.46 * * *$ & $-5.65 * * *$ & $-51.33 * * *$ & $1.15^{* * *}$ & $1.11^{* * *}$ & $0.78 * * *$ \\
\hline & {$[0.000]$} & {$[0.000]$} & {$[0.000]$} & {$[0.000]$} & {$[0.000]$} & {$[0.000]$} \\
\hline \multirow{2}{*}{ FirmSize $^{2}$} & $1.11 * *$ & $0.16^{* * *}$ & $2.36^{* * *}$ & $-0.04 * * *$ & $-0.04 * * *$ & $-0.02 * * *$ \\
\hline & [0.017] & {$[0.000]$} & {$[0.000]$} & {$[0.000]$} & {$[0.000]$} & {$[0.000]$} \\
\hline \multirow{2}{*}{ CDF of Variance } & $42.88^{* * *}$ & $9.91^{* * *}$ & $27.94^{* * *}$ & $0.76^{* * *}$ & $0.75^{* * *}$ & $0.21^{* * *}$ \\
\hline & {$[0.002]$} & {$[0.000]$} & {$[0.000]$} & {$[0.000]$} & {$[0.000]$} & {$[0.002]$} \\
\hline \multirow{2}{*}{$\mathrm{M} / \mathrm{B}$} & $2.01^{* * *}$ & $0.57 * * *$ & $2.35^{* * *}$ & $0.06^{* * *}$ & $0.08 * * *$ & $0.07 * * *$ \\
\hline & {$[0.000]$} & {$[0.000]$} & {$[0.000]$} & {$[0.000]$} & {$[0.000]$} & {$[0.000]$} \\
\hline \multirow{2}{*}{ ROE } & $19.92 * * *$ & $4.39 * * *$ & $16.49 * * *$ & $0.54 * * *$ & $0.53 * * *$ & $0.34^{* * *}$ \\
\hline & {$[0.000]$} & {$[0.000]$} & {$[0.000]$} & {$[0.000]$} & {$[0.000]$} & {$[0.000]$} \\
\hline \multirow{2}{*}{ Leverage } & $-33.92 * * *$ & $-1.59 * *$ & $-17.69 * * *$ & $-0.34^{* *}$ & $-0.21 * * *$ & $-0.64 * * *$ \\
\hline & {$[0.000]$} & {$[0.04]$} & {$[0.000]$} & {$[0.04]$} & {$[0.01]$} & {$[0.000]$} \\
\hline \multirow{2}{*}{ Age } & $1.770 * * *$ & $0.37^{* * *}$ & $1.14^{* * *}$ & $0.042^{* * *}$ & $0.044 * * *$ & $0.05^{* * *}$ \\
\hline & {$[0.000]$} & {$[0.000]$} & {$[0.000]$} & {$[0.000]$} & {$[0.000]$} & {$[0.000]$} \\
\hline \multirow{2}{*}{ Cash } & $33.766^{* *}$ & $7.16^{* * *}$ & 4.76 & $0.55 * * *$ & $0.76^{* * *}$ & $0.25^{* * *}$ \\
\hline & {$[0.014]$} & {$[0.000]$} & {$[0.41]$} & {$[0.000]$} & {$[0.000]$} & {$[0.006]$} \\
\hline \multirow{2}{*}{ Stockreturn } & $51.66^{* * *}$ & $10.91^{* * *}$ & $45.01^{* * *}$ & $1.26 * * *$ & $1.29 * * *$ & $1.14^{* * *}$ \\
\hline & {$[0.000]$} & {$[0.000]$} & {$[0.000]$} & {$[0.000]$} & {$[0.000]$} & {$[0.000]$} \\
\hline Year Dummy & Yes & Yes & Yes & Yes & Yes & Yes \\
\hline Industry Dummy & Yes & Yes & No & Yes & Yes & No \\
\hline Firm Fixed Effects & No & No & Yes & No & No & Yes \\
\hline \multirow{2}{*}{ Intercept } & $59.44^{* *}$ & $19.01 * * *$ & $208.35^{* * *}$ & $-3.89 * * *$ & $-3.97 * * *$ & $-2.87 * * *$ \\
\hline & {$[0.037]$} & {$[0.000]$} & {$[0.000]$} & {$[0.000]$} & {$[0.000]$} & {$[0.000]$} \\
\hline $\mathrm{N}$ & 13314 & 13314 & 13314 & 13314 & 13314 & 13314 \\
\hline $\begin{array}{l}\text { Adjusted-R2/ } \\
\text { Pseudo R2 }\end{array}$ & $18.5 \%$ & $5.8 \%$ & $22.6 \%$ & $47 \%$ & $29 \%$ & $39 \%$ \\
\hline
\end{tabular}




\section{Panel B: Using Ln(Volume) as the Proxy for Hedging Cost}

The sample consists of 10,123 firm-year observations from 1996 to 2005. All of the observations have their options traded on U.S. option exchanges. Pay-performance sensitivity (PPS) is calculated as the dollar value change of the stock and options held by a CEO for per $\$ 1,000$ shareholders return. Portfolio equity incentive (PEI) is the sensitivity of the total value of stock and options held by a CEO to $1 \%$ change in stock price, and PEI is measured in \$thousand. Volume is the average number of daily option contracts traded. $\mathrm{Ln}()$ denotes the natural logarithm transform. Industry dummies are constructed based on Fama and French (1997)'s 48 industries. Corresponding p-values are reported in brackets. The p-values for OLS regressions are based on robust standard errors clustered at the firm level. The p-values for median regressions are according to bootstrapped standard errors based on 20 replications. The notation $* * *, * *$ and $*$ denote statistical significance at the $1 \%, 5 \%$ and $10 \%$ level, respectively.

\begin{tabular}{|c|c|c|c|c|c|c|}
\hline & (1) & (2) & (3) & (4) & (5) & (6) \\
\hline & $P P S$ & PPS & PPS & $\operatorname{Ln}(P E I)$ & $\operatorname{Ln}(P E I)$ & $\operatorname{Ln}(P E I)$ \\
\hline & OLS & Median & Fixed Effect & OLS & Median & Fixed Effect \\
\hline \multirow{2}{*}{ Ln(Volume) } & $3.57^{* * *}$ & $1.14^{* * *}$ & $6.77^{* * *}$ & $0.11^{* * *}$ & $0.12^{* * *}$ & $0.13^{* * *}$ \\
\hline & {$[0.004]$} & {$[0.000]$} & [0.000] & {$[0.000]$} & {$[0.000]$} & {$[0.000]$} \\
\hline \multirow{2}{*}{ FirmSize } & $-30.71 * * *$ & $-8.21^{* * *}$ & $-63.76^{* * *}$ & $1.15^{* * *}$ & $1.01^{* * *}$ & $0.68^{* * *}$ \\
\hline & {$[0.000]$} & {$[0.000]$} & {$[0.000]$} & {$[0.000]$} & {$[0.000]$} & {$[0.000]$} \\
\hline \multirow{2}{*}{ FirmSize $^{2}$} & $1.03 * *$ & $0.23 * * *$ & $2.69 * * *$ & $-0.05 * * *$ & $-0.04 * * *$ & $-0.02 * * *$ \\
\hline & {$[0.026]$} & {$[0.000]$} & {$[0.000]$} & {$[0.000]$} & {$[0.000]$} & {$[0.001]$} \\
\hline \multirow{2}{*}{ CDF of Variance } & $42.36^{* * *}$ & $5.36^{* * *}$ & 4.41 & $0.58 * * *$ & $0.45^{* * *}$ & $-0.25^{* * *}$ \\
\hline & {$[0.000]$} & {$[0.000]$} & {$[0.41]$} & {$[0.001]$} & {$[0.000]$} & [0.007] \\
\hline \multirow{2}{*}{$\mathrm{M} / \mathrm{B}$} & $2.21^{* * *}$ & $0.57 * * *$ & $2.38^{* * *}$ & $0.06^{* * *}$ & $0.07^{* * *}$ & $0.07^{* * *}$ \\
\hline & {$[0.000]$} & {$[0.000]$} & {$[0.000]$} & {$[0.000]$} & {$[0.000]$} & {$[0.000]$} \\
\hline \multirow{2}{*}{ ROE } & $14.21^{* * *}$ & $4.05^{* * *}$ & $15.71^{* * *}$ & $0.48 * * *$ & $0.48 * * *$ & $0.34^{* * *}$ \\
\hline & {$[0.003]$} & {$[0.000]$} & {$[0.000]$} & {$[0.000]$} & {$[0.000]$} & {$[0.000]$} \\
\hline \multirow{2}{*}{ Leverage } & $-35.52 * * *$ & $-3.13^{* * *}$ & $-23.17 * * *$ & $-0.47 * *$ & $-0.32 * * *$ & $-0.67 * * *$ \\
\hline & {$[0.000]$} & {$[0.000]$} & {$[0.000]$} & [0.012] & {$[0.001]$} & {$[0.001]$} \\
\hline \multirow{2}{*}{ Age } & $1.76^{* * *}$ & $0.35^{* * *}$ & $1.29 * * *$ & $0.04^{* * *}$ & $0.05^{* * *}$ & $0.05^{* * *}$ \\
\hline & {$[0.000]$} & {$[0.000]$} & {$[0.000]$} & {$[0.000]$} & {$[0.000]$} & {$[0.000]$} \\
\hline \multirow{2}{*}{ Cash } & 19.08 & $6.13^{* * *}$ & 1.97 & $0.44^{* *}$ & $0.75^{* * *}$ & $0.35^{* * *}$ \\
\hline & {$[0.12]$} & {$[0.000]$} & {$[0.75]$} & [0.034] & {$[0.000]$} & {$[0.001]$} \\
\hline \multirow{2}{*}{ Stockreturn } & $47.62 * * *$ & $9.78^{* * *}$ & $41.59 * * *$ & $1.21^{* * *}$ & $1.24 * * *$ & $1.09^{* * *}$ \\
\hline & {$[0.000]$} & {$[0.000]$} & {$[0.000]$} & {$[0.000]$} & {$[0.000]$} & {$[0.000]$} \\
\hline Year Dummy & Yes & Yes & Yes & Yes & Yes & Yes \\
\hline Industry Dummy & Yes & Yes & No & Yes & Yes & No \\
\hline Firm Fixed Effects & No & No & Yes & No & No & Yes \\
\hline \multirow{2}{*}{ Intercept } & $96.00^{* * *}$ & $34.19 * * *$ & $256.29 * * *$ & $-3.61 * * *$ & $-3.35 * * *$ & $-2.64 * * *$ \\
\hline & {$[0.006]$} & {$[0.000]$} & {$[0.000]$} & {$[0.000]$} & {$[0.000]$} & {$[0.000]$} \\
\hline $\mathrm{N}$ & 9837 & 9837 & 9837 & 9837 & 9837 & 9837 \\
\hline $\begin{array}{l}\text { Adjusted-R2/ } \\
\text { Pseudo R2 }\end{array}$ & $19.5 \%$ & $6.3 \%$ & $25.3 \%$ & $43.5 \%$ & $27 \%$ & $41.5 \%$ \\
\hline
\end{tabular}


Table 3. Managerial Hedging Cost and Sensitivity of CEO Wealth to Stock Volatility

The sample consists of 13,314 firm-year observations from 1996 to 2005. In the sample, 10,123 firm-year observations have their options traded on U.S. option exchanges. The dependent variable is $L n($ Vega) and Vega (in \$thousand) is calculated as the dollar value change of the stock and options held by a CEO for 0.01 change in standard deviation of stock return. Option is a dummy variable which equals to one if the firm's option is traded on U.S. option exchanges, and zero otherwise. Volume is the average number of daily option contracts traded. $L n()$ denotes the natural logarithm transform. Industry dummies are constructed based on Fama and French (1997)'s 48 industries. Corresponding p-values are reported in brackets. The p-values for OLS regressions are based on robust standard errors clustered at the firm level. The p-values for median regressions are according to bootstrapped standard errors based on 20 replications. The notation $* * *, * *$ and $*$ denote statistical significance at the $1 \%, 5 \%$ and $10 \%$ level, respectively.

\begin{tabular}{|c|c|c|c|c|c|c|}
\hline & $\begin{array}{c}(1) \\
\text { OLS }\end{array}$ & $\begin{array}{r}(2) \\
\text { Median }\end{array}$ & $\begin{array}{c}(3) \\
\text { Fixed Effect }\end{array}$ & $\begin{array}{l}\text { (4) } \\
\text { OLS }\end{array}$ & $\begin{array}{c}(5) \\
\text { Median }\end{array}$ & $\begin{array}{c}(6) \\
\text { Fixed Effect }\end{array}$ \\
\hline Ontion & $0.17^{* * *}$ & $0.09 * * *$ & $0.09 * * *$ & & & \\
\hline Option & {$[0.005]$} & {$[0.000]$} & {$[0.001]$} & & & \\
\hline Ln(Volume) & & & & $\begin{array}{l}0.12^{* * *} \\
{[0.000]}\end{array}$ & $\begin{array}{l}0.11^{* * *} \\
{[0.000]}\end{array}$ & $\begin{array}{l}0.07 * * * \\
{[0.000]}\end{array}$ \\
\hline FirmSize & $\begin{array}{l}0.52^{* * *} \\
{[0.000]}\end{array}$ & $\begin{array}{l}0.71^{* * *} \\
{[0.000]}\end{array}$ & $\begin{array}{l}0.26^{* * *} \\
{[0.000]}\end{array}$ & $\begin{array}{l}0.44^{* * *} \\
{[0.008]}\end{array}$ & $\begin{array}{l}0.65^{* * *} \\
{[0.000]}\end{array}$ & $\begin{array}{l}0.08 \\
{[0.359]}\end{array}$ \\
\hline FirmSize $^{2}$ & $\begin{array}{l}0.005 \\
{[0.618]}\end{array}$ & $\begin{array}{l}-0.006^{*} \\
{[0.095]}\end{array}$ & $\begin{array}{l}0.016^{* * *} \\
{[0.000]}\end{array}$ & $\begin{array}{l}0.001 \\
{[0.912]}\end{array}$ & $\begin{array}{l}-0.01 * * \\
{[0.041]}\end{array}$ & $\begin{array}{l}0.02^{* * *} \\
{[0.000]}\end{array}$ \\
\hline CDF of Variance & $\begin{array}{l}0.28 * * \\
{[0.04]}\end{array}$ & $\begin{array}{l}0.29 * * * \\
{[0.000]}\end{array}$ & $\begin{array}{l}0.09 \\
{[0.18]}\end{array}$ & $\begin{array}{l}-0.43^{* *} \\
{[0.011]}\end{array}$ & $\begin{array}{l}-0.23^{* * *} \\
{[0.001]}\end{array}$ & $\begin{array}{l}-0.16^{*} \\
{[0.08]}\end{array}$ \\
\hline M/B & $\begin{array}{l}-0.04 * * * \\
{[0.000]}\end{array}$ & $\begin{array}{l}-0.02 * * * \\
{[0.000]}\end{array}$ & $\begin{array}{l}-0.03 * * * \\
{[0.000]}\end{array}$ & $\begin{array}{l}-0.04 * * * \\
{[0.000]}\end{array}$ & $\begin{array}{l}-0.03 * * * \\
{[0.000]}\end{array}$ & $\begin{array}{l}-0.03 * * * \\
{[0.000]}\end{array}$ \\
\hline ROE & $\begin{array}{l}0.07 \\
{[0.336]}\end{array}$ & $\begin{array}{l}-0.05 \\
{[0.310]}\end{array}$ & $\begin{array}{l}0.03 \\
{[0.480]}\end{array}$ & $\begin{array}{l}0.11 \\
{[0.211]}\end{array}$ & $\begin{array}{l}0.02 \\
{[0.814]}\end{array}$ & $\begin{array}{l}0.04 \\
{[0.414]}\end{array}$ \\
\hline Leverage & $\begin{array}{l}0.97 * * * \\
{[0.000]}\end{array}$ & $\begin{array}{l}0.85 * * * \\
{[0.000]}\end{array}$ & $\begin{array}{l}0.33 * * * \\
{[0.000]}\end{array}$ & $\begin{array}{l}0.94^{* * *} \\
{[0.000]}\end{array}$ & $\begin{array}{l}0.79 * * * \\
{[0.000]}\end{array}$ & $\begin{array}{l}0.39 * * * \\
{[0.000]}\end{array}$ \\
\hline Age & $\begin{array}{l}-0.02 * * * \\
{[0.000]}\end{array}$ & $\begin{array}{l}-0.01 * * * \\
{[0.000]}\end{array}$ & $\begin{array}{l}-0.01^{* * *} \\
{[0.000]}\end{array}$ & $\begin{array}{l}-0.02 * * * \\
{[0.000]}\end{array}$ & $\begin{array}{l}-0.01 * * * \\
{[0.000]}\end{array}$ & $\begin{array}{l}-0.01^{* * *} \\
{[0.000]}\end{array}$ \\
\hline Cash & $\begin{array}{l}-0.02 \\
{[0.941]}\end{array}$ & $\begin{array}{l}0.42 * * * \\
{[0.000]}\end{array}$ & $\begin{array}{l}0.21 * * \\
{[0.026]}\end{array}$ & $\begin{array}{l}0.06 \\
{[0.801]}\end{array}$ & $\begin{array}{l}0.38 * * * \\
{[0.000]}\end{array}$ & $\begin{array}{l}0.18^{*} \\
{[0.077]}\end{array}$ \\
\hline Stockreturn & $\begin{array}{l}0.34^{* * *} \\
{[0.000]}\end{array}$ & $\begin{array}{l}0.36 * * * \\
{[0.000]}\end{array}$ & $\begin{array}{l}0.29 * * * \\
{[0.000]}\end{array}$ & $\begin{array}{l}0.28^{* * *} \\
{[0.000]}\end{array}$ & $\begin{array}{l}0.31 * * * \\
{[0.000]}\end{array}$ & $\begin{array}{l}0.25^{* * *} \\
{[0.000]}\end{array}$ \\
\hline Year Dummy & Yes & Yes & Yes & Yes & Yes & Yes \\
\hline Industry Dummy & Yes & Yes & No & Yes & Yes & No \\
\hline Firm Fixed Effects & No & No & Yes & No & No & Yes \\
\hline Intercept & $\begin{array}{l}-0.32 \\
{[0.554]}\end{array}$ & $\begin{array}{l}-1.56^{* * *} \\
{[0.000]}\end{array}$ & $\begin{array}{l}0.83^{* * *} \\
{[0.002]}\end{array}$ & $\begin{array}{l}0.24 \\
{[0.732]}\end{array}$ & $\begin{array}{l}-1.08^{* * *} \\
{[0.001]}\end{array}$ & $\begin{array}{l}1.68^{* * *} \\
{[0.000]}\end{array}$ \\
\hline $\mathrm{N}$ & 13422 & 13422 & 13422 & 9919 & 9919 & 9919 \\
\hline $\begin{array}{l}\text { Adjusted-R2/ } \\
\text { Pseudo R2 }\end{array}$ & $37 \%$ & $29 \%$ & $22 \%$ & $35 \%$ & $27 \%$ & $22 \%$ \\
\hline
\end{tabular}


Table 4. Simultaneous Equations (3SLS): Managerial Hedging Cost, Pay-performance Sensitivity, and Sensitivity of CEO Wealth to Stock Volatility

The sample consists of 13,314 firm-year observations from 1996 to 2005. In the sample, 10,123 firm-year observations have their options traded on U.S. option exchanges. The jointly determined variables are $L n$ (Vega) and $L n(P E I)$. The variable Option is a dummy variable which equals to one if the firm's option is traded on U.S. option exchanges, and zero otherwise. Volume is the average number of daily option contracts traded. $\operatorname{Ln}()$ denotes the natural logarithm transform. Industry dummies are constructed based on Fama and French (1997)'s 48 industries. Corresponding p-values are reported in brackets. The notation $* * *, * *$ and $*$ denote statistical significance at the $1 \%, 5 \%$ and $10 \%$ level, respectively.

(1)

(2)

(3)

(4)

\begin{tabular}{|c|c|c|c|c|}
\hline & Ln(Vega) & Ln(PEI) & Ln(Vega) & Ln(PEI) \\
\hline \multirow{2}{*}{ Ln(PEI) } & $-0.61 * * *$ & & $-0.58 * * *$ & \\
\hline & {$[0.000]$} & & {$[0.000]$} & \\
\hline \multirow{2}{*}{ Ln(Vega) } & & -0.030 & & $-0.14 * * *$ \\
\hline & & [0.336] & & {$[0.000]$} \\
\hline \multirow{2}{*}{ Option } & $0.16^{* * *}$ & $0.06 * *$ & & \\
\hline & {$[0.000]$} & [0.039] & & \\
\hline \multirow{2}{*}{ Ln(Volume) } & & & $0.16^{* * *}$ & $0.12^{* * *}$ \\
\hline & & & {$[0.000]$} & {$[0.000]$} \\
\hline \multirow{2}{*}{ FirmSize } & $1.11^{* * *}$ & $1.16^{* * *}$ & $1.03 * * *$ & $1.21^{* * *}$ \\
\hline & {$[0.000]$} & {$[0.000]$} & {$[0.000]$} & {$[0.000]$} \\
\hline \multirow{2}{*}{ FirmSize $^{2}$} & $-0.022 * * *$ & $-0.038 * * *$ & $-0.028 * * *$ & $-0.046 * * *$ \\
\hline & {$[0.000]$} & {$[0.000]$} & {$[0.000]$} & {$[0.000]$} \\
\hline \multirow{2}{*}{ Variance } & $0.81^{* * *}$ & $0.76^{* * *}$ & 0.14 & $0.53^{* * *}$ \\
\hline & {$[0.000]$} & [0.001] & [0.18] & {$[0.000]$} \\
\hline \multirow{2}{*}{$\mathrm{M} / \mathrm{B}$} & $0.018^{* * *}$ & $0.061^{* * *}$ & $0.012^{* *}$ & $0.057^{* * *}$ \\
\hline & {$[0.001]$} & {$[0.000]$} & [0.044] & {$[0.000]$} \\
\hline \multirow{2}{*}{ ROE } & $0.35^{* * *}$ & $0.54 * * *$ & $0.32^{* * *}$ & $0.50^{* * *}$ \\
\hline & {$[0.000]$} & {$[0.000]$} & {$[0.000]$} & {$[0.000]$} \\
\hline \multirow{2}{*}{ Leverage } & $0.42 * * *$ & $-0.31 * * *$ & $0.41^{* * *}$ & $-0.32 * * *$ \\
\hline & {$[0.000]$} & [0.001] & {$[0.000]$} & {$[0.001]$} \\
\hline \multirow{2}{*}{ Age } & & $0.04 * * *$ & & $0.04^{* * *}$ \\
\hline & & {$[0.000]$} & & {$[0.000]$} \\
\hline \multirow{2}{*}{ Cash } & $0.41^{* * *}$ & $0.55^{* * *}$ & $0.41^{* * *}$ & $0.44^{* * *}$ \\
\hline & {$[0.000]$} & {$[0.000]$} & [0.001] & {$[0.000]$} \\
\hline \multirow{2}{*}{ Stockreturn } & $0.92^{* * *}$ & $1.26^{* * *}$ & $0.84^{* * *}$ & $1.24^{* * *}$ \\
\hline & {$[0.000]$} & {$[0.000]$} & {$[0.000]$} & {$[0.000]$} \\
\hline \multirow{2}{*}{ Ln(Cash Compensation) } & $0.56^{* * *}$ & & $0.47^{* * *}$ & \\
\hline & {$[0.000]$} & & {$[0.000]$} & \\
\hline Year\&Industry Dummy & Yes & Yes & Yes & Yes \\
\hline \multirow{2}{*}{ Intercept } & $-5.24 * * *$ & $-3.84 * * *$ & $-4.18 * * *$ & $-3.51 * * *$ \\
\hline & {$[0.000]$} & {$[0.000]$} & {$[0.000]$} & {$[0.000]$} \\
\hline $\mathrm{N}$ & 13314 & 13314 & 9837 & 9837 \\
\hline R2 & $19 \%$ & $46 \%$ & $18 \%$ & $43 \%$ \\
\hline
\end{tabular}




\section{Table 5. Regression Analysis on Capital Structure}

The sample consists of 59,381 firm-year observations from 1996 to 2005. I obtain stock price data in CRSP, accounting data in Compustat, and option trading data in OptionMetrics. In the sample, 17,638 firm-year observations have their options traded on U.S. option exchanges. The dependent variable is the firm-level leverage ratio, measured by both book leverage and market leverage. Book leverage (in percentage) is defined as the book value of long-term debt / total assets; market leverage (in percentage) is the book value of long-term debt / (book value of long-term debt + market value of equity). Option is a dummy variable which equals to one if the firm's option is traded on U.S. option exchanges, and zero otherwise. Volume is the average number of daily option contracts traded. Tangibility is computed as the ratio of the firm's fixed assets over total assets. $R \& D$ is the ratio of the firm's $\mathrm{R} \& \mathrm{D}$ expenses to sales. Advertising is the firm's advertising expenses to sales. Ln() denotes the natural logarithm transform. Industry dummies are constructed based on Fama and French (1997)'s 48 industries. Corresponding p-values from robust standard errors clustered at the firm level are reported in brackets. The notation $* * *$, $* *$ and $*$ denote statistical significance at the $1 \%, 5 \%$ and $10 \%$ level, respectively.

\begin{tabular}{|c|c|c|c|c|}
\hline & $\begin{array}{c}\text { (1) } \\
\text { Book } \\
\text { Leverage }\end{array}$ & $\begin{array}{c}(2) \\
\text { Book } \\
\text { Leverage }\end{array}$ & $\begin{array}{c}\text { (3) } \\
\text { Market } \\
\text { Leverage }\end{array}$ & $\begin{array}{c}\text { (4) } \\
\text { Market } \\
\text { Leverage }\end{array}$ \\
\hline Option & $\begin{array}{c}2.19 * * * \\
{[0.000]}\end{array}$ & & $\begin{array}{l}1.04 * * * \\
{[0.000]}\end{array}$ & \\
\hline Ln(Volume) & & $\begin{array}{l}0.74^{* * *} \\
{[0.000]}\end{array}$ & & $\begin{array}{l}0.55^{* * *} \\
{[0.000]}\end{array}$ \\
\hline FirmSize & $\begin{array}{c}0.27 * * * \\
{[0.002]}\end{array}$ & $\begin{array}{c}-0.50 * \\
{[0.055]}\end{array}$ & $\begin{array}{l}-0.15^{* *} \\
{[0.018]}\end{array}$ & $\begin{array}{c}-0.82 * * * \\
{[0.000]}\end{array}$ \\
\hline StockReturn & $\begin{array}{c}-0.51 * * * \\
{[0.001]}\end{array}$ & $\begin{array}{c}0.32 \\
{[0.327]}\end{array}$ & $\begin{array}{c}-0.36 * * * \\
{[0.000]}\end{array}$ & $\begin{array}{c}0.35 * \\
{[0.075]}\end{array}$ \\
\hline CDF of Variance & $\begin{array}{c}0.79 * * \\
{[0.035]}\end{array}$ & $\begin{array}{c}0.26 \\
{[0.81]}\end{array}$ & $\begin{array}{c}-0.68 * * \\
{[0.02]}\end{array}$ & $\begin{array}{l}-1.29 * \\
{[0.06]}\end{array}$ \\
\hline $\mathrm{M} / \mathrm{B}$ & $\begin{array}{c}-0.84 * * * \\
{[0.000]}\end{array}$ & $\begin{array}{c}-1.25 * * * \\
{[0.000]}\end{array}$ & $\begin{array}{c}-1.51 * * * \\
{[0.000]}\end{array}$ & $\begin{array}{c}-1.91 * * * \\
{[0.000]}\end{array}$ \\
\hline ROE & $\begin{array}{c}0.21 \\
{[0.186]}\end{array}$ & $\begin{array}{c}0.19 \\
{[0.628]}\end{array}$ & $\begin{array}{c}0.24^{* * *} \\
{[0.009]}\end{array}$ & $\begin{array}{c}-0.17 \\
{[0.402]}\end{array}$ \\
\hline Tangibility & $\begin{array}{c}23.18^{* * *} \\
{[0.000]}\end{array}$ & $\begin{array}{c}19.52^{* * *} \\
{[0.000]}\end{array}$ & $\begin{array}{c}18.78^{* * *} \\
{[0.000]}\end{array}$ & $\begin{array}{c}15.21^{* * *} \\
{[0.000]}\end{array}$ \\
\hline $\mathrm{R} \& \mathrm{D}$ & $\begin{array}{c}-0.000 \\
{[0.846]}\end{array}$ & $\begin{array}{c}-0.003^{* * *} \\
{[0.000]}\end{array}$ & $\begin{array}{c}-0.001 \\
{[0.137]}\end{array}$ & $\begin{array}{c}-0.001^{* * *} \\
{[0.000]}\end{array}$ \\
\hline Advertising & $\begin{array}{c}-0.02 \\
{[0.308]}\end{array}$ & $\begin{array}{c}-0.14 \\
{[0.767]}\end{array}$ & $\begin{array}{c}-0.01 \\
{[0.195]}\end{array}$ & $\begin{array}{c}-0.22 \\
{[0.456]}\end{array}$ \\
\hline Year\&Industry Dummies & Yes & Yes & Yes & Yes \\
\hline Intercept & $\begin{array}{c}9.52 * * * \\
{[0.000]}\end{array}$ & $\begin{array}{c}12.46^{* * *} \\
{[0.000]}\end{array}$ & $\begin{array}{c}10.43^{* * *} \\
{[0.000]}\end{array}$ & $\begin{array}{c}13.96^{* * *} \\
{[0.000]}\end{array}$ \\
\hline $\mathrm{N}$ & 59381 & 17638 & 59381 & 17638 \\
\hline Adjusted-R2 & $15 \%$ & $16 \%$ & $19 \%$ & $23 \%$ \\
\hline
\end{tabular}




\section{Table 6. Regression Analysis on Executive Option Holding}

\section{Panel A: Using Option Dummy as the Proxy for Hedging Cost}

The sample consists of 13,314 firm-year observations from 1996 to 2005. In the sample, 10,123 firm-year observations have their options traded on U.S. option exchanges. Opt1 is the dollar value of the exercisable in-the-money options held by the CEO, measured in 2000-constant dollars. Opt2 is calculated as Opt1 over the CEO's total annual income. Opt3 is the ratio of Opt1 over the firm's stock capitalization. Both Opt1 and Opt2 are measured in percentage. Opt4 is defined as the number of shares of vested in-the-money option as the percentage of the firm's stock shares owned by the CEO. Opt5 is computed as the number of shares of vested in-the-money option as the percentage of the firm's total shares outstanding. Option is a dummy variable which equals to one if the firm's option is traded on U.S. option exchanges, and zero otherwise. Ownership is the percentage of the firm's shares owned by the CEO. Industry dummies are constructed based on Fama and French (1997)'s 48 industries. Corresponding p-values from robust standard errors clustered at the firm level are reported in brackets. The notation ***, $* *$ and $*$ denote statistical significance at the $1 \%, 5 \%$ and $10 \%$ level, respectively.

\begin{tabular}{|c|c|c|c|c|c|}
\hline & $\begin{array}{c}(1) \\
\operatorname{Ln}(1+O p t 1) \\
\end{array}$ & $\begin{array}{c}(2) \\
\operatorname{Ln}(1+O p t 2) \\
\end{array}$ & $\begin{array}{c}(3) \\
\operatorname{Ln}(1+O p t 3)\end{array}$ & $\begin{array}{c}(4) \\
\operatorname{Ln}(1+O p t 4)\end{array}$ & $\begin{array}{c}\text { (5) } \\
\operatorname{Ln}(1+\text { Opt5) }\end{array}$ \\
\hline \multirow{2}{*}{ Option } & $0.41^{* * *}$ & $0.22 * * *$ & $0.03^{* * *}$ & $0.09 * *$ & $0.03^{* * *}$ \\
\hline & {$[0.000]$} & {$[0.000]$} & {$[0.000]$} & {$[0.033]$} & {$[0.003]$} \\
\hline \multirow{2}{*}{ FirmSize } & $0.61 * * *$ & $0.21 * * *$ & $-0.04 * * *$ & $0.05^{* * *}$ & $-0.10^{* * *}$ \\
\hline & {$[0.000]$} & {$[0.000]$} & {$[0.000]$} & {$[0.000]$} & {$[0.000]$} \\
\hline \multirow{2}{*}{ CDF of Variance } & 0.19 & -0.09 & $0.10^{* * *}$ & $0.19 * * *$ & 0.18 \\
\hline & {$[0.41]$} & [0.59] & {$[0.000]$} & {$[0.000]$} & {$[0.27]$} \\
\hline \multirow{2}{*}{ Ownership } & $-7.69 * * *$ & $-3.33 * * *$ & $-0.08 * * *$ & $-19.35 * * *$ & $-0.64^{* * *}$ \\
\hline & {$[0.000]$} & {$[0.000]$} & {$[0.000]$} & {$[0.000]$} & {$[0.000]$} \\
\hline \multirow{2}{*}{$\mathrm{M} / \mathrm{B}$} & $0.17 * * *$ & $0.14^{* * *}$ & $0.02 * * *$ & 0.001 & $0.01^{* * *}$ \\
\hline & {$[0.000]$} & {$[0.000]$} & {$[0.000]$} & [0.925] & {$[0.000]$} \\
\hline \multirow{2}{*}{ Age } & 0.004 & $0.005^{*}$ & $0.001^{*}$ & $-0.023 * * *$ & $0.002 * * *$ \\
\hline & [0.318] & [0.087] & {$[0.086]$} & {$[0.000]$} & {$[0.000]$} \\
\hline \multirow{2}{*}{ StockReturn } & $2.52^{* * *}$ & $1.66^{* * *}$ & $0.12 * * *$ & -0.057 & $-0.02 * *$ \\
\hline & {$[0.000]$} & {$[0.000]$} & {$[0.000]$} & [0.175] & [0.023] \\
\hline $\begin{array}{l}\text { Year\&Industry } \\
\text { Dummies }\end{array}$ & Yes & Yes & Yes & Yes & Yes \\
\hline \multirow{2}{*}{ Intercept } & -0.38 & 0.45 & $0.27^{* * *}$ & $4.56^{* * *}$ & $0.94^{* * *}$ \\
\hline & [0.595] & [0.343] & {$[0.000]$} & {$[0.000]$} & {$[0.000]$} \\
\hline $\mathrm{N}$ & 13689 & 13689 & 13554 & 13682 & 13263 \\
\hline Adjusted-R2 & $30.6 \%$ & $30.6 \%$ & $32 \%$ & $28 \%$ & $28 \%$ \\
\hline
\end{tabular}

\section{Panel B: Using Ln(Volume) as the Proxy for Hedging Cost}

The sample consists of 10,123 firm-year observations have their options traded on U.S. option exchanges. Volume is the average number of daily option contracts traded. $\operatorname{Ln}()$ denotes the natural logarithm transform. The regression models are the same with those in Panel A, except that I replace Option with Ln(Volume). Coefficients for other controls (not reported) are similar to those in Panel A.

\begin{tabular}{lccccc}
\hline & $(1)$ & $(2)$ & $(3)$ & $(4)$ & $(5)$ \\
& $L n(1+O p t 1)$ & $L n(1+O p t 2)$ & $L n(1+O p t 3)$ & $L n(1+O p t 4)$ & $L n(1+O p t 5)$ \\
\hline \multirow{2}{*}{ Ln(Volume) } & $\mathbf{0 . 0 9 8 * * *}$ & $\mathbf{0 . 0 2 8}$ & $\mathbf{0 . 0 2 1} * * *$ & $\mathbf{0 . 0 9 2 * * *}$ & $\mathbf{0 . 0 2 4 * * *}$ \\
& {$[\mathbf{0 . 0 0 0}]$} & {$[\mathbf{0 . 1 2 6}]$} & {$[\mathbf{0 . 0 0 0}]$} & {$[\mathbf{0 . 0 0 0 ]}$} & {$[\mathbf{0 . 0 0 0}]$} \\
\hline
\end{tabular}


Table 7. Regression Analysis on Corporate Dividend Policy

The sample consists of 17,036 firm-year observations from 1997 to 2006. In the sample, 11,247 firm-year observations have their options traded on U.S. option exchanges. The dependent variable is the firm-level dividend payment (Compustat Item 21) normalized by the firm's stock market capitalization. Option is a dummy variable which equals to one if the firm's option is traded on U.S. option exchanges, and zero otherwise. Volume is the average number of daily option contracts traded. Optionpay is the Black-Scholes value of the CEO's annual option grant normalized by her total annual compensation. Optionwealth is the Black-Scholes value of the CEO's total option holding. Ln() denotes the natural logarithm transform. Industry dummies are constructed based on Fama and French (1997)'s 48 industries. Corresponding $\mathrm{p}$-values from robust standard errors clustered at the firm level are reported in brackets. The notation ***, ** and * denote statistical significance at the $1 \%, 5 \%$ and $10 \%$ level, respectively.

\begin{tabular}{|c|c|c|c|c|}
\hline & (1) & (2) & (3) & (4) \\
\hline Optionpay & $\begin{array}{c}-1.22 * * * \\
{[0.000]}\end{array}$ & & $\begin{array}{c}-0.76^{* * *} \\
{[0.000]}\end{array}$ & \\
\hline Ln(Optionwealth) & & $\begin{array}{c}-0.053^{* * *} \\
{[0.000]}\end{array}$ & & $\begin{array}{c}-0.041^{* * *} \\
{[0.000]}\end{array}$ \\
\hline Option $\times$ Optionpay & $\begin{array}{c}0.71 * * * \\
{[0.000]}\end{array}$ & & & \\
\hline Option $\times$ Ln(Optionwealth) & & $\begin{array}{l}0.02 * * * \\
{[0.005]}\end{array}$ & & \\
\hline Ln(Volume) $\times$ Optionpay & & & $\begin{array}{c}0.05 * * * \\
{[0.004]}\end{array}$ & \\
\hline Ln(Volume) × Ln(Optionwealth) & & & & $\begin{array}{c}0.001 \\
{[0.487]}\end{array}$ \\
\hline Option & $\begin{array}{c}-0.54 * * * \\
{[0.000]}\end{array}$ & $\begin{array}{c}-0.55^{* * *} \\
{[0.000]}\end{array}$ & & \\
\hline Ln(Volume) & & & $\begin{array}{c}-0.20 * * * \\
{[0.000]}\end{array}$ & $\begin{array}{c}-0.21^{* * *} \\
{[0.000]}\end{array}$ \\
\hline FirmSize & $\begin{array}{c}0.13^{* * *} \\
{[0.000]}\end{array}$ & $\begin{array}{c}0.15^{* * *} \\
{[0.000]}\end{array}$ & $\begin{array}{c}0.33^{* * *} \\
{[0.000]}\end{array}$ & $\begin{array}{c}0.37^{* * *} \\
{[0.000]}\end{array}$ \\
\hline CDF of Variance & $\begin{array}{c}-3.02 * * * \\
{[0.000]}\end{array}$ & $\begin{array}{c}-3.12^{* * *} \\
{[0.000]}\end{array}$ & $\begin{array}{c}-2.59 * * * \\
{[0.000]}\end{array}$ & $\begin{array}{c}-2.63 * * * \\
{[0.000]}\end{array}$ \\
\hline $\mathrm{M} / \mathrm{B}$ & $\begin{array}{c}-0.05^{* * *} \\
{[0.000]}\end{array}$ & $\begin{array}{c}-0.04^{* * *} \\
{[0.000]}\end{array}$ & $\begin{array}{c}-0.05^{* * *} \\
{[0.000]}\end{array}$ & $\begin{array}{c}-0.04^{* * *} \\
{[0.000]}\end{array}$ \\
\hline ROE & $\begin{array}{c}0.02 \\
{[0.429]}\end{array}$ & $\begin{array}{c}0.09 * * * \\
{[0.002]}\end{array}$ & $\begin{array}{c}0.06^{*} \\
{[0.066]}\end{array}$ & $\begin{array}{l}0.12^{* * *} \\
{[0.001]}\end{array}$ \\
\hline Leverage & $\begin{array}{c}0.23^{* * *} \\
{[0.000]}\end{array}$ & $\begin{array}{l}0.22 * * * \\
{[0.000]}\end{array}$ & $\begin{array}{c}0.49 * * * \\
{[0.000]}\end{array}$ & $\begin{array}{l}0.48^{* * *} \\
{[0.000]}\end{array}$ \\
\hline Cash & $\begin{array}{c}-0.43^{* * *} \\
{[0.000]}\end{array}$ & $\begin{array}{c}-0.53^{* * *} \\
{[0.000]}\end{array}$ & $\begin{array}{c}-0.38 * * * \\
{[0.000]}\end{array}$ & $\begin{array}{c}-0.42^{* * *} \\
{[0.000]}\end{array}$ \\
\hline Year\&Industry Dummies & Yes & Yes & Yes & Yes \\
\hline Intercept & $\begin{array}{c}0.59 * * * \\
{[0.000]}\end{array}$ & $\begin{array}{c}0.62 * * * \\
{[0.000]}\end{array}$ & $\begin{array}{c}-0.57 * * * \\
{[0.002]}\end{array}$ & $\begin{array}{c}-0.54 * * * \\
{[0.009]}\end{array}$ \\
\hline $\mathrm{N}$ & 16991 & 17036 & 11247 & 11246 \\
\hline Adjusted-R2 & $35.9 \%$ & $36.2 \%$ & $36.4 \%$ & $37.3 \%$ \\
\hline
\end{tabular}




\section{Table 8. Regression Analysis on Corporate Diversification}

The sample consists of 52,472 firm-year observations from 1996 to 2005. I obtain stock price data in CRSP, accounting data in Compustat, and option trading data in OptionMetrics. In the sample, 16,369 firm-year observations have their options traded on U.S. option exchanges. The dependent variables are Herfindahl Index and natural logarithm of number of business segments. Herfindahl Index is calculated as the sum of the square of segment sales divided by the square of firm sales. Option is a dummy variable which equals to one if the firm's option is traded on U.S. option exchanges, and zero otherwise. Volume is the average number of daily option contracts traded. $\operatorname{Ln}()$ denotes the natural logarithm transform. Industry dummies are constructed based on Fama and French (1997)'s 48 industries. Corresponding p-values from robust standard errors clustered at the firm level are reported in brackets. The notation $* * *$, ** and * denote statistical significance at the $1 \%, 5 \%$ and $10 \%$ level, respectively.

(1)

(2)

(3)

(4)

\begin{tabular}{|c|c|c|c|c|}
\hline & Herfindahl Index & Herfindahl Index & Ln(segments) & Ln(segments) \\
\hline \multirow{2}{*}{ Option } & $0.017 * * *$ & & $-0.041 * * *$ & \\
\hline & {$[0.001]$} & & {$[0.002]$} & \\
\hline \multirow{2}{*}{ Ln(Volume) } & & $0.004^{*}$ & & 0.003 \\
\hline & & {$[0.066]$} & & [0.644] \\
\hline \multirow{2}{*}{ FirmSize } & $-0.027 * * *$ & $-0.028 * * *$ & $0.073^{* * *}$ & $0.058 * * *$ \\
\hline & {$[0.000]$} & {$[0.000]$} & {$[0.000]$} & {$[0.000]$} \\
\hline \multirow{2}{*}{ StockReturn/100 } & $0.27^{* * *}$ & $0.20 * *$ & $-0.61 * * *$ & $-0.56^{* *}$ \\
\hline & {$[0.000]$} & {$[0.042]$} & {$[0.000]$} & {$[0.023]$} \\
\hline \multirow{2}{*}{ CDF of Variance } & $0.08^{* * *}$ & $0.13^{* * *}$ & $-0.21 * * *$ & $-0.39 * * *$ \\
\hline & {$[0.000]$} & {$[0.000]$} & {$[0.000]$} & {$[0.000]$} \\
\hline \multirow{2}{*}{$\mathrm{M} / \mathrm{B} / 100$} & $0.41^{* * *}$ & $0.42 * * *$ & $-1.12 * * *$ & $-1.13^{* * *}$ \\
\hline & {$[0.000]$} & {$[0.000]$} & {$[0.000]$} & {$[0.000]$} \\
\hline \multirow{2}{*}{ ROE/100 } & $0.91^{* * *}$ & $1.16^{* * *}$ & $-2.59 * * *$ & $-3.48 * * *$ \\
\hline & {$[0.001]$} & {$[0.002]$} & {$[0.000]$} & {$[0.000]$} \\
\hline \multirow{2}{*}{ Cash } & $0.13^{* * *}$ & $0.15^{* * *}$ & $-0.35 * * *$ & $-0.41 * * *$ \\
\hline & {$[0.000]$} & {$[0.000]$} & {$[0.000]$} & {$[0.000]$} \\
\hline \multirow{2}{*}{ Leverage } & $-0.057 * * *$ & $-0.043^{* *}$ & $0.147 * * *$ & $0.094^{*}$ \\
\hline & {$[0.000]$} & [0.029] & {$[0.000]$} & {$[0.058]$} \\
\hline Year\&Industry Dummies & Yes & Yes & Yes & Yes \\
\hline \multirow{2}{*}{ Intercept } & $0.97^{* * *}$ & $0.98^{* * *}$ & 0.072 & 0.012 \\
\hline & [0.000] & {$[0.000]$} & [0.152] & [0.925] \\
\hline $\mathrm{N}$ & 51532 & 16220 & 52472 & 16369 \\
\hline Adjusted-R2 & $20 \%$ & $26 \%$ & $24 \%$ & $31 \%$ \\
\hline
\end{tabular}

